\title{
An Experimental Characterization of Shear Wave Velocity (V-s) in Clean and Hydrocarbon-Contaminated Sand
}

\section{DOI:}

10.1007/s10706-017-0274-0

\section{Document Version}

Accepted author manuscript

Link to publication record in Manchester Research Explorer

\section{Citation for published version (APA):}

Rajabi, H., \& Sharifipour, M. (2017). An Experimental Characterization of Shear Wave Velocity (V-s) in Clean and Hydrocarbon-Contaminated Sand. Geotechnical and Geological Engineering, 35(6), 2727-2745.

https://doi.org/10.1007/s10706-017-0274-0

\section{Published in:}

Geotechnical and Geological Engineering

\section{Citing this paper}

Please note that where the full-text provided on Manchester Research Explorer is the Author Accepted Manuscript or Proof version this may differ from the final Published version. If citing, it is advised that you check and use the publisher's definitive version.

\section{General rights}

Copyright and moral rights for the publications made accessible in the Research Explorer are retained by the authors and/or other copyright owners and it is a condition of accessing publications that users recognise and abide by the legal requirements associated with these rights.

\section{Takedown policy}

If you believe that this document breaches copyright please refer to the University of Manchester's Takedown Procedures [http://man.ac.uk/04Y6Bo] or contact uml.scholarlycommunications@manchester.ac.uk providing relevant details, so we can investigate your claim.

\section{OPEN ACCESS}




\section{Geotechnical and Geological Engineering An experimental characterization of shear wave velocity (Vs) in clean and hydrocarbon-contaminated sand --Manuscript Draft--}

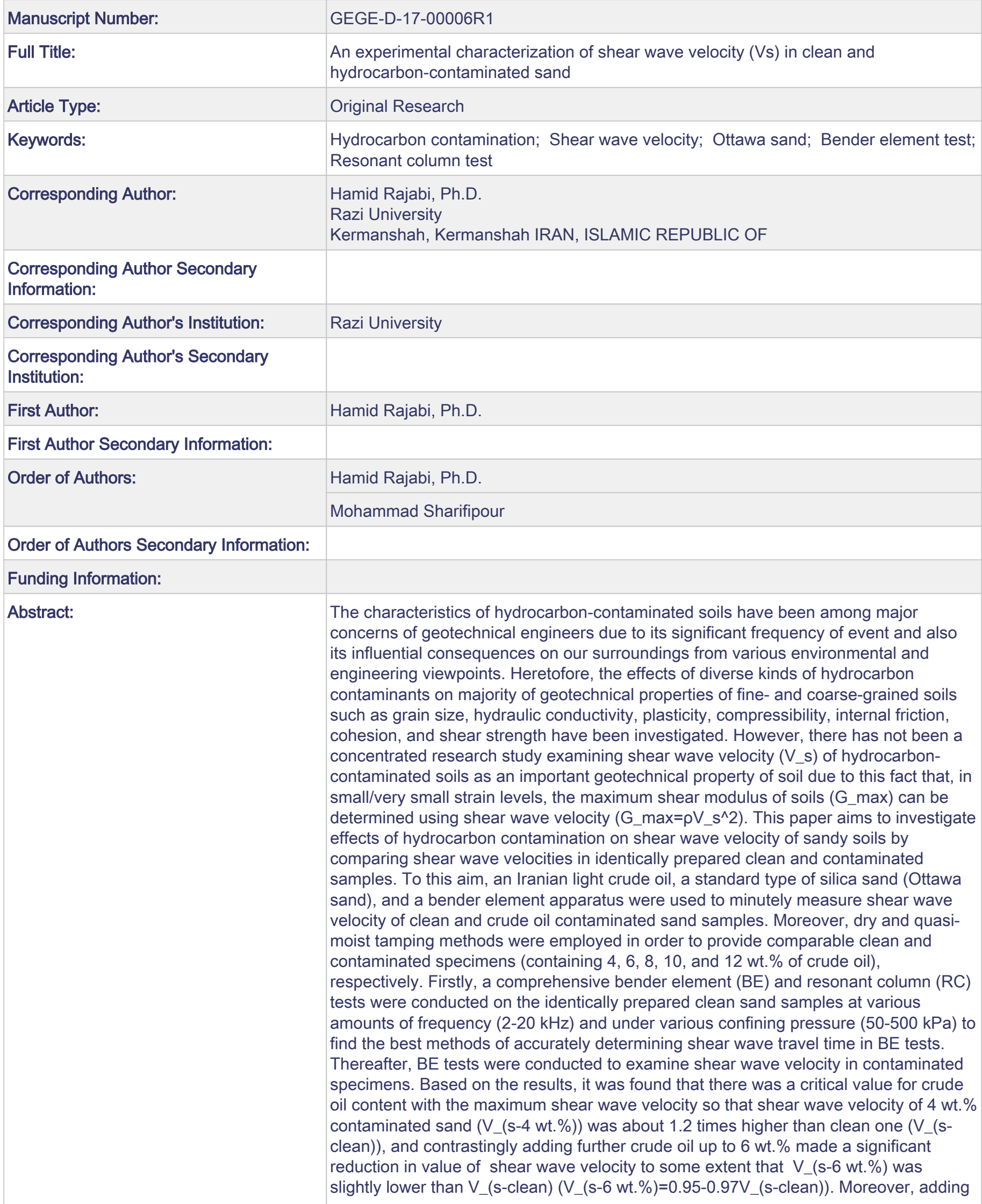


more contaminant (8-12 wt. \%) into sand had negligible influences on shear wave velocity. In this paper, the effects of crude oil contamination on sand microstructure were also evaluated using scanning electron microscopy.

First and foremost, the authors profoundly thank Reviewer\#1 for assessing the submitted paper to GEGE and for valuable comments. In general, all of the proposed corrections have been implemented into the manuscript, and their corresponding responses have been also presented as follows:

Reviewer \#1: The paper entitled "An experimental characterization of shear wave velocity (Vs) in clean and hydrocarbon-contaminated sand" is an interesting paper presenting the results of the study examining shear wave velocity $(\mathrm{Vs})$ of hydrocarbon contaminated soils, so it can be accepted for publication in GEGE after minor revisions.

1.The chapters of the paper need an improvement in English and especially a careful reading from a reviewer who can fluently speak English and can adequately use geoscience terminology.

Response: According to the reviewer's comment, the manuscript has been carefully reviewed and rechecked in terms of English language, and some changes have been implemented, and highlighted in yellow throughout the manuscript.

2.References should be improved.

Response: It should be stated that the authors used Endnote software Ver. X7.40 (Thomson Reuters) along with specific Endnote style for GEGE journal to manage references in this manuscript. All in all, based on the reviewer's comment, all references have been controlled again.

3.Authors should consider and cite some other papers about S-waves measurements in sandy soils such as: Cavallaro et al. (2012) on the Monte Po hill on "Soil Dynamics and Earthquake Engineering", by Castelli et al. (2016) on the microzonation of the city of Catania on "Soil Dynamics and Earthquake Engineering", by Cavallaro et al. (2013a; b) Geotechnical and Geophysical Site Characterization 4 on the site characterisation in the

Genova Harbour (Italy), on the seismic microzonation studies for the city of Ragusa (Italy) on "Soil Dynamics and Earthquake Engineering", by Grasso and Maugeri (2014) on the liquefaction potential evaluation at Catania Harbour (Italy) by WIT PRESS.

Response: Thanks to the reviewer's comment, these research articles have been cited as extra references in the introduction section of the manuscript in order to emphasize significance of determining shear wave velocity of soils in seismic and earthquake ground response analysis. The added references have been highlighted in yellow in the manuscript as well as the reference section.

Response to Reviewer\#2's comments:

Above all, the authors would like to deeply thank Reviewer\#2 for assessing our submitted article to GEGE and for valuable comments. In general, all of the proposed corrections have been implemented into manuscript, and their corresponding responses have been also presented as follows:

Reviewer \#2:

1.The paper needs to revise in terms of writing.

Response: According to the reviewer's comment, the manuscript has been carefully reviewed and rechecked in terms of English language, and some changes have been implemented, and highlighted in yellow throughout the manuscript.

2.In the abstract, the research methodology is not clearly expressed. Response: Based on the reviewer's comment, a brief explanation of research methodology has been added in the abstract (highlighted in yellow).

3.In the introduction, a few examples of literature review should be briefly express. Response: To this aim, an extra paragraph (highlighted in yellow) was embedded in the introduction of the manuscript which concisely describes some remarkable findings 
provided in the literature regarding important characteristics of hydrocarboncontaminated soils.

4.Geological map of sampling locations should be add in manuscript.

Response: As explained in the section 2.1., section 2.2., and section 2.6. in the manuscript, in this research, hydrocarbon-contaminated specimens of Ottawa sand were prepared by the researchers in the lab so as to provide homogenous samples with specific contents of crude oil $(4,6,8,10,12 \mathrm{wt} . \%)$ for the purpose of assessing influences of crude oil on shear wave velocity (Vs) in hydrocarbon-contaminated sand. Thus, in the proposed research, there was not any in-situ sampling process.

5. The assessment results are not well analyzed in current text.

Response: Based on the reviewer's comment, further explanations have been added in the section 3.3. of the manuscript in order to justify and analyze the observed findings in more details (highlighted in yellow).

6. The results presented in the conclusion are ambiguous and not clearly expressed. Response: To elucidate the context of the manuscript in the conclusion (section 4), the authors rewrote/added some parts of the conclusion, and highlighted them in yellow. It was tired to point to the main conclusions more clearly.

7.In conclusion, Shortcoming of research methodology should be describe. Response: In this regard, the subsection of 4 has been added in the conclusion section.

8. Given the aforementioned main critical issues, I think this manuscript is suitable for publication after major revise.

Response: Many thanks again for your time devoted to assess the submitted article. The authors tried to accurately make your desired corrections into the manuscript. 
1

3

\title{
An experimental characterization of shear wave
}

\section{velocity $\left(V_{s}\right)$ in clean and hydrocarbon-}

\section{contaminated sand}

\author{
Hamid Rajabi*, Mohammad Sharifipour
}

Department of Civil Engineering, Faculty of Engineering, Razi University,

Kermanshah 67149, Iran

\footnotetext{
* Corresponding author

Tel.: +98 8334274535

E-mail: ham.rajabi@gmail.com

hamid_rajabi@razi.ac.ir
} 
velocity of 4 wt.\% contaminated sand $\left(\mathrm{V}_{\mathrm{s}-4 \mathrm{wt} . \%}\right)$ was about 1.2 times higher than clean one $\left(\mathrm{V}_{\mathrm{s}-\text { clean }}\right)$, and contrastingly adding further crude oil up to $6 \mathrm{wt} . \%$ made a significant reduction in value of shear wave velocity to some extent that $\mathrm{V}_{\mathrm{s}-6 \mathrm{wt} . \%}$ was slightly lower than $\mathrm{V}_{\mathrm{s}-\text { clean }}$ $\left(\mathrm{V}_{\mathrm{s}-6 \mathrm{wt} . \%}=0.95-0.97 \mathrm{~V}_{\mathrm{s}-\text { clean }}\right)$. Moreover, adding more contaminant $(8-12 \mathrm{wt} . \%)$ into sand had negligible influences on shear wave velocity. In this paper, the effects of crude oil contamination on sand microstructure were also evaluated using scanning electron microscopy.

Keywords: Hydrocarbon contamination; Shear wave velocity; Ottawa sand; Bender element test; Resonant column test;

\section{Introduction}

Hydrocarbon contamination as one of considerable types of soil contamination has been greatly highlighted so far due to its significant frequency of events and also influential aftereffects on our ecosystem from diverse environmental and engineering aspects (Mirsal 2004). Besides destructive effects of hydrocarbon contamination on our surrounding environment, the consequences of hydrocarbon contaminants on physical, chemical, and engineering properties of soil have been a serious matter due to remarkable applications of soil in geotechnical applications. To this aim, several research studies have been conducted so far so as to evaluate behavior of hydrocarbon contaminated soil, and various physical and chemical properties of hydrocarbon contaminated soils along with their geotechnical characteristics have been concentrated in the literature. Generally speaking, the natural or artificial presence of several types of hydrocarbon compounds into fine- and coarse-grained soils including heavy/light crude oil (Aiban 1998; Al-Sanad et al. 1995; Cook et al. 1992; Kermani and Ebadi 2012; Khamehchiyan et al. 2007; Naeini and Shojaedin 2014; Puri et al. 1994; Shin et al. 1999; Singh 
et al. 2009; Srivastava and Pandey 1997; Tuncan and Pamukcu 1992), used motor oil (Evgin and Das 1992; Ijimdiya 2013; Nasr 2013; Nazir 2011; Silvestri et al. 1997; Singh et al. 2009), bitumen (Ola 1991), benzene (Al-Sanad et al. 1995; Al-Sanad and Ismael 1997), gas oil (Alhassan and Fagge 2013; Khosravi et al. 2013; Nasr 2013), used engine oil (Akinwumi et al. 2014b; Shin and Das 2001; Siang et al. 2014; Singh et al. 2008), lamp oil (Shin et al. 2002), diesel (Pusadkar and Bharambe 2014; Singh et al. 2008; Solly et al. 2015; Walia et al. 2013), gasoline (Di Matteo et al. 2011; Singh et al. 2008), and palm biodiesel (Ling and Yong 2013) were considered by the researchers.

Based on a general review on the relevant literature to geotechnical properties of hydrocarbon contaminated soils, it can be totally stated that various physical, chemical, and geotechnical properties of hydrocarbon contaminated soils including particle size distribution (PSD) (Akinwumi et al. 2014a; Al-Sanad et al. 1995; Ijimdiya 2013; Jia et al. 2010; Nazir 2011; Silvestri et al. 1997; Srivastava and Pandey 1997; Talukdar and Saikia 2013), plasticity (Alhassan and Fagge 2013; Jia et al. 2010; Kermani and Ebadi 2012; Khamehchiyan et al. 2007; Khosravi et al. 2013; Nazir 2011; Rahman et al. 2010a; Solly et al. 2015; Srivastava and Pandey 1997; Ukpong and Umoh 2015; Walia et al. 2013), hydraulic conductivity (Akinwumi et al. 2014a; Akinwumi et al. 2014b; Al-Sanad et al. 1995; Budhu et al. 1991; Foreman and Daniel 1986; Khamehchiyan et al. 2007; Meegoda and Rajapakse 1993; Rahman et al. 2010b; Siang et al. 2014; Singh et al. 2008; Uppot and Stephenson 1989), optimum moisture content (OMC) (Akinwumi et al. 2014a; Akinwumi et al. 2014b; Alhassan and Fagge 2013; Cook et al. 1992; Ijimdiya 2013; Jia et al. 2010; Ochepo and Joseph 2014; Ola 1991; Onyelowe 2015; Oyegbile and Ayininuola 2013; Puri et al. 1994; Rahman et al. 2007; Rahman et al. 2010a; Rahman et al. 2010b; Silvestri et al. 1997; Singh et al. 2009; Solly et al. 2015; Srivastava and Pandey 1997; 
Talukdar and Saikia 2013; Ukpong and Umoh 2015; Walia et al. 2013), maximum dry density (MDD) (Akinwumi et al. 2014a; Al-Sanad et al. 1995; Kermani and Ebadi 2012; Khamehchiyan et al. 2007; Onyelowe 2015; Puri 2000; Rahman et al. 2010b; Singh et al. 2009; Solly et al. 2015; Srivastava and Pandey 1997; Ukpong and Umoh 2015; Walia et al. 2013), compression index (Cc) (Al-Sanad et al. 1995; Alhassan and Fagge 2013; Di Matteo et al. 2011; Estabragh et al. 2016; Ijimdiya 2013; Khosravi et al. 2013; Meegoda and Ratnaweera 1994; Nazir 2011; Onyelowe 2015; Singh et al. 2008; Talukdar and Saikia 2013), angle of internal friction (AlSanad et al. 1995; Cook et al. 1992; Evgin and Das 1992; Khamehchiyan et al. 2007; Puri 2000; Shin et al. 2002; Siang et al. 2014; Singh et al. 2008; Srivastava and Pandey 1997), cohesion (Jia et al. 2010; Khamehchiyan et al. 2007; Khosravi et al. 2013; Siang et al. 2014; Singh et al. 2009), and so on have been examined in the literature.

In a general view, it can be concluded according to the previously mentioned literature that hydrocarbon contaminants have ability to greatly alter soil microstructure and PSD specifications. In coarse-grained soil, hydrocarbon-coated particles with bigger sizes can create a new form in soil structure, and change basic physical properties of soil. However, in fine-grained soil, due to increments in soil particle size, dissolution of soluble composite colloids and salts in pore fluid (hydrocarbon), loss of cohesion/contact among soil grains, and so on, substantial changes in soil PSD and microstructure are imaginable so that the number of bigger-sized particles increases and soil structure changes into a flocculated state. As a well-confirmed phenomenon, hydraulic conductivity of hydrocarbon-contaminated soils (both fine- and coarsegrained soils) is obviously lower than that of clean ones as a result of placements of hydrocarbon compounds into soil pores. Regarding compaction behavior of hydrocarbon-contaminated soils, the related literature revealed that almost in most cases hydrocarbons could noticeably reduce the 
value of OMC; however, there was no unique trend about hydrocarbon-induced changes in MDD to be cited here, and it depended on various factors such as soil properties and hydrocarbon types. As one of the most challenging aspects of hydrocarbon-contaminated soils, it is a burdensome task to draw a clear-cut conclusion about plasticity of contaminated soils due to this fact that there was not a general procedure describing effects of hydrocarbons on Atterberg limits of soils, and this particular property of soils is dependent on a variety of physical and chemical characteristics. Based on the majority of the literature explaining consolidation of hydrocarboncontaminated soils, it can be said that hydrocarbon contamination can generally increase compression index $\left(\mathrm{C}_{\mathrm{c}}\right)$ of soil; however, there was no definite trend to be mentioned here about effects of hydrocarbon compounds on over consolidation ratio (OCR) and swelling index (Cr) of soil. In addition, although hydrocarbons can bring about negative influences (diminishing effects) on internal friction angle of sandy soils, an artificial cohesion among particles can be observed in hydrocarbon-contaminated sands.

All in all, to the best of our knowledge, it can be stated at this stage based on the literature review conducted by the authors that there has not been a centralized experimental study focusing on influences of hydrocarbon contamination on shear wave velocity of soils as a substantial geotechnical characteristic in small/very small strain problems such as design of machine foundation, deep excavation examination (Dyvik and Madshus 1986; Viggiani and Atkinson 1995), and earthquake ground response analysis (Castelli et al. 2016; Cavallaro et al. 2012; Cavallaro et al. 2013a; Cavallaro et al. 2013b; Grasso and Maugeri 2014; Maugeri and Grasso 2013). Generally speaking, several experimental apparatus have been introduced/utilized in the literature to determine shear wave velocity of soils including bender elements system, resonant column apparatus, and also torsional shear test (Yamashita et al. 2009). It is worth mentioning 
that bender elements and resonant column tests have been successfully employed separately and/or simultaneously in numerous written scientific works to precisely measure shear wave velocity of soils under various circumstances as a result of their prominent advantages such as non-destructiveness, simplicity, and rapidity as well as their compatibilities in order to be assembled with the other common geotechnical testing equipment (Cai et al. 2015; Gu et al. 2013; Murillo et al. 2011).

In the present paper, the authors make an effort to experimentally concentrate on influences of a specific hydrocarbon on shear wave velocity of a type of standard silica sand using a bender element system under various conditions. In this regard, an Iranian light crude oil was used as the contaminant, and Ottawa sand was considered as the standard silica sand. In order to provide the possibility of carefully comparing shear wave velocity of clean and contaminated specimens, all testing samples were similarly prepared with identical void ratio.

\section{Materials and methods}

\subsection{Silica sand}

In this study, a type of standard sand, Ottawa sand, has been used as a basic kind of silica sand. The used Ottawa sand consisted of naturally light yellow particles of almost pure quartz, and was supplied by Amitis Azma Company in Iran. In Fig. 1, an image of the used sand under an ovendried clean condition and its SEM images with three different magnifications have been presented (50X, 100X, and 250X). The particle size distribution (PSD) curve of the used Ottawa sand has been provided in Fig. 2 along with PSD curves of standard Ottawa sand described in details by (ASTM 2009). It can be apparently observed in Fig. 2 that PSD curve of the used Ottawa sand was located between the defined boundaries according to the standard (ASTM 
2009), and it can be also confirmed based on the curves that the used sand was appropriately in accordance with the standard ones. Moreover, basic properties of the used Ottawa sand have been listed in Table 1 along with those of the standard ones (ASTM 2009). Precisely speaking, it can be inferred from the table that specific gravity of all sands was identical, and the value of $\mathrm{D}_{10}, \mathrm{D}_{60}$, and $\mathrm{D}_{30}$ of the used Ottawa sand as well as its coefficient of uniformity $\left(\mathrm{C}_{\mathrm{u}}\right)$ were between those of the standard ones. However, the coefficient of curvature $\left(\mathrm{C}_{\mathrm{c}}\right)$ of the used Ottawa sand was slightly higher than those of the standard ones. In addition, chemical composition of the used Ottawa sand (hereafter Ottawa sand) provided by the supplier was listed in Table 2. Based on the chemical analysis, more than 97 percent of the sand mass consisted of silicon dioxide $\left(\mathrm{SiO}_{2}\right)$ or silica, and the rest can be categorized as iron(III) oxide $\left(\mathrm{Fe}_{2} \mathrm{O}_{3}\right)$, Aluminum oxide $\left(\mathrm{Al}_{2} \mathrm{O}_{3}\right)$, potassium oxide $\left(\mathrm{k}_{2} \mathrm{O}\right)$, calcium oxide $(\mathrm{CaO})$, magnesium oxide (MgO) or magnesia, and sodium oxide $\left(\mathrm{Na}_{2} \mathrm{O}\right)$.

\subsection{Crude oil}

In this research, a type of Iranian light crude oil supplied by West Oil and Gas Production Company (WOGPC) of Iran was used as a hydrocarbon contaminant. In Table 3, some basic properties of the crude oil have been presented based on the data provided by WOGPC.

\subsection{Scanning electron microscopy (SEM)}

In order to profoundly investigate microstructure of crude oil contaminated Ottawa sand samples and to visually compare clean and contaminated specimens, a series of SEM images has been captured by a scanning electron microscopy apparatus (KYKY - EM3200, China). The SEM 
images were created at 26000 Volt with a scale bar of 10 and 100 um as well as a variety of magnifications $(50 \mathrm{X}, 100 \mathrm{X}, 250 \mathrm{X}, 1.0 \mathrm{kX}$, and $5.0 \mathrm{kX})$

\subsection{Test equipment}

In this research, it was tried to concentrate on influences of crude oil contamination on shear wave velocity of a standard type of silica sand (Ottawa sand). To this aim, a digitally controlled triaxial testing apparatus made by STRASSENTEST OHG Company (Germany) was utilized as a host device and equipped by two bender elements (BE). These elements were assembled in an additional passive triaxial cell provided by Soil Mechanics Industry of Iran (SMI). Moreover, the configuration of bender elements in the additional cell were bottom-fixed/top-free (Fig. 3), and dimensions of each bender element were $22.15 \mathrm{~mm}$ in width, $3.80 \mathrm{~mm}$ in thickness, and 10.90 $\mathrm{mm}$ in protruding depth. As a part of bender element system, a dual-channel arbitrary waveform generator (AG 1022F made by Owan product line, Fujian Lilliput Optoelectronics Technology Co., Ltd., China) was used as a wave generator, and also a digital double-channel storage oscilloscope (GDS-1052-U made by GW Instek, Good Will Instrument Co., Ltd., Taiwan) was employed to accurately record transmitted and received signals. In this study, sinusoidal waveforms with frequency range of $2-20 \mathrm{kHz}$ and amplitude of $22 \mathrm{mV}$ were created by the wave generator device. In experimental tests, the delay times caused by wiring connections between devices were exactly measured under the circumstances of direct tip-to-tip contacted bender elements (Fig. 4), and were scrupulously considered in velocity calculations. The triaxial testing apparatus had a digitally controlled water constant pressure system providing isotropic confining

pressures up to $2000 \pm 1 \mathrm{kPa}$. It is worth noting that, during all experiments and at the end of all steps of applying confining pressure, the vertical displacements of samples were precisely 
recorded by a linear variable displacement transducer (LVDT) (STRASSENTEST OHG, Germany), and took into consideration in order to accurately calculate tip-to-tip distance between elements as the confirmed shear wave travel distance in the bender element systems (Dyvik and Madshus 1986; Gu et al. 2013; Jovičić et al. 1996; Lee and Santamarina 2005; Viggiani and Atkinson 1995; Yamashita et al. 2009). In order to appropriately tackle unwanted electromagnetic induction throughout all testing devices including triaxial testing apparatus, wave generator, oscilloscope, bender-equipped passive triaxial cell, etc., a systematic earth loop with an extensive wiring configuration was used in this study. Furthermore, graphical software was provided by Soil Mechanics Industry of Iran in order to enable users to accurately record transmitted and received signals in more details.

\subsection{Resonant Column Test}

In order to validate results of bender element tests and to select the best methods of determining shear wave travel time in BE tests, a serious of resonant column (RC) test on clean Ottawa sand specimens (under identical conditions with the BE tests) was offered to International Institute of Earthquake Engineering and Seismology of Iran (IIEES) in order to separately conduct some RC tests under completely similar circumstances by use of their resonant column apparatus (made by Seiken, Inc., Japan). The used RC instrument had the capability to provide confining pressure up to $1000 \pm 1 \mathrm{kPa}$ and frequency range of $10-300 \mathrm{kHz}$.

\subsection{Sample preparation and test procedure}

This section aims at describing all experimental procedure of preparing clean and crude oil contaminated Ottawa sand samples. In this regard, all Ottawa sand specimens were firstly oven- 
dried for approximately 48 hours so as to completely remove any existing amount of moisture in the sand. After passing almost 2 days, all oven-dried sand samples were brought out from the oven, and instantly left in the insulated containers so as to cool down to the lab condition. Thereafter, an electrically powered soil stirring device was used to thoroughly mix the cooled specimens with the considered amounts of crude oil $(4,6,8,10,12$ wt.\% of oven-dried Ottawa sand) and to appropriately provide uniform crude oil contaminated sand. This range of contamination was chosen based on influential amounts of crude oil contamination cited in the previously mentioned relevant literature. After preparation of contaminated sand samples, the specimens were kept in the sealed plastic containers under normal circumstances for almost 72 hours to approach an adequate and acceptable state of homogeneity. To prepare cylindrical BE test specimens, a two-way split aluminum sampling mold with internal diameter of $105 \mathrm{~mm}$ (F03586, STRASSENTEST OHG, Germany) equipped with a rubber membrane was used. In this research, in order to prepare identical clean and contaminated sand samples, dry and quasimoist tamping method were utilized, respectively. In this regard, both methods aimed at providing 5-layer cylindrical sand samples (101-102 $\mathrm{mm}$ in diameter) with an identical void ratio. In the case of clean sand sample, an adequate amount (according to the considered void ratio) of cooled oven-dried Ottawa sand was poured into the sampling mold by use of a plastic funnel (nozzle diameter of $7.0 \mathrm{~mm}$ ) with no falling gap. After the first layer was primarily become full of the sand, the layer surface was concurrently compacted by a 650 -gr aluminum pounder (diameter of $85 \mathrm{~mm}$ ) and minutely leveled with an absolute digimatic caliper (Mitutoyo, Japan) to obtain the desired void ratio in the first layer. Thereafter, the procedure of preparing the first layer was repeated for subsequent layers with some differences in compactive efforts (Cai et al. 2015). It is worth mentioning that after reaching an acceptable level of compactness in each 
layer, layer surface was properly roughened by a mild flat brush to create an adequate interfacial roughness between the layers. Regarding contaminated specimens, 3-day aged crude oil contaminated Ottawa sands (with oil content of 4, 6, 8, 10, and 12 wt.\%) were brought out from the sealed containers, and used for quasi-moist tamping method. In this regard, the steps of sample preparation were generally similar to those of dry tamping method with a few changes in compactive efforts and sample height to reach the same void ratio. Afterwards, the top-free bender element was appropriately assembled with a properly o-ringed head (and bottom), and then a suction of almost $30 \mathrm{kPa}$ was provided by use of a lab scale vacuum pump (Platinum series, JB Industry, USA) to sustain the sample in the vertical direction. It should be mentioned here that, according to primary calibration tests, an appropriate assemblage of top-free bender element was provided so that similar initial polarization in the recorded wave signal was obtained in all tests. After releasing two-way split aluminum sampling mold, the perspex cell was carefully placed and tightly connected to the base pedestal to provide well-fitting condition for applying water constant pressure. To add to that, in all experiments, a tight pneumatic configuration was used to continuously/invariantly produce the considered amounts of isotropic confining pressure $(50-500 \mathrm{kPa})$. More importantly, during the first step of confinement, the suction of $30 \mathrm{kPa}$ was gradually eliminated with increasing confining pressure to $30 \mathrm{kPa}$ in order to protect the fresh sample from being shocked. In the testing procedure, specimens were isotropically confined up to $500 \mathrm{kPa}$ through 10 steps so that in each step a confining pressure of $50 \mathrm{kPa}$ was added to the previous one. After each step, the vertical displacement of sample was accurately recorded using LVDT, and used in the calculation of tip-to-tip distance between the elements. It is worth noting that, in this experimental study, the vertical displacement was recorded as the only index assessing volume change in the sand. 


\section{Results and discussion}

\subsection{Determination of shear wave travel time}

According to the relevant literature, it is usually assumed in bender element tests that the velocity of shear wave $\left(\mathrm{V}_{\mathrm{S}}\right)$ can be calculated as a ratio of $\mathrm{L} / \mathrm{T}$ in which $\mathrm{L}$ and $\mathrm{T}$ are travel distance and travel time of shear wave, respectively (Dyvik and Madshus 1986; Viggiani and Atkinson 1995). Moreover, it should be stated that determination of soil shear wave velocity in small and very small strain conditions is significant due to this fact that soil maximum shear modulus ( $G_{\max }$ or $\mathrm{G}_{0}$ ) can be calculated using $\mathrm{V}_{\mathrm{s}}$ via $\mathrm{G}_{\max }=\rho \mathrm{V}_{\mathrm{s}}^{2}$ (where $\rho$ is the density of soil) (Viggiani and Atkinson 1995). As a generally accepted assumption (Yamashita et al. 2009), shear wave travel distance in bender element tests has been assumed to be identical to the closest tip-to-tip distance between two elements. Accordingly, in this research, any alteration in the distance between the elements which might be caused by volume change due to confining pressure was exactly/incessantly measured and recorded in the end of each step of confinement. However, an accurate determination of shear wave travel time ( $\mathrm{T}$ ) in a bender element test has always been a challenging issue due to the intrinsic uncertainty and subjectivity of bender element system (Cai et al. 2015; Gu et al. 2013; Kumar and Madhusudhan 2010; Murillo et al. 2011; Viggiani and Atkinson 1995; Yamashita et al. 2009). As more detailed explanation, a transmitted shear wave in a bender element test is usually accompanied by a boundary-induced compression wave so that a combination of these both waves in the receiver element may make a complex situation in determining precise shear wave travel time. This issue was named as near-field-effect (NFE) in the literature (Arroyo et al. 2006; Brignoli et al. 1996). The near-effect phenomenon has been greatly observed in soil with small amount of moisture due to minor difference between shear and compression wave velocity in soil under dry condition (Yamashita et al. 2009). In general, 
the arrival time of shear wave can be concealed by the NFE due to this fact that shear wave velocity $\left(\mathrm{V}_{\mathrm{s}}\right)$ might be close to the velocity of boundary-induced compression wave $\left(\mathrm{V}_{\mathrm{p}}\right)$. Moreover, it should be mentioned here that the near-field-effect is generally a dispersive phenomenon (frequency-dependent event), and it can be anticipated that the influences of NFE can be altered by changing frequency (Yamashita et al. 2009). Heretofore, several research studies have been profoundly concentrated on bender element tests in order to characterize origins and effects of NFE (Arroyo et al. 2006; Arulnathan et al. 1998; Brignoli et al. 1996; Jovičić et al. 1996; Lee and Santamarina 2005; Leong et al. 2009; Presti et al. 1997; SanchezSalinero 1987; Viggiani and Atkinson 1995). In this regard, it has been tried to propose practical guidelines and suggestions so as to lessen influences of NFE on the recorded results of bender element tests. For this purpose, a rule suggested by Jovicic et al. and thereafter confirmed by Brignoli et al. and Lo Presti et al. described that the shape of received wave signal in a bender element test can be controlled by a ratio of the length (L) travelled by the wave with the effective wavelength $(\lambda)$ and frequency (f) $\left(R_{d}=L / \lambda\right)$ (Brignoli et al. 1996; Jovičić et al. 1996; Presti et al. 1997). Precisely speaking, these researchers stated that the NFE has been prominently determined for the amounts of $R_{d}$ which were between 0.25 and 4 , especially close to 1.0. However, for higher values of $R_{d}\left(R_{d} \geq 4.0\right)$, the influences of near-field phenomenon were greatly alleviated, and the researchers were perfectly able to determine an accurate shear wave travel time. Meanwhile, it should be also stated that Sanchez-Salinero (Sanchez-Salinero 1987) proposed that the amount of $R_{d}$ should be identical to 2.0 in order to control the NFE. In line with Jovicic et al., Brignoli et al., and Lo Presti et al., Arroyo in 2006 suggested that $R_{d}$ should be higher than 1.60 in order to reduce the NFE (Arroyo et al. 2006). In addition, to weaken the effects of near effects, Leong et al. (Leong et al. 2009) also suggested that it would be better to 
design the configuration of bender element tests with the amount of $R_{d}$ greater than 3.33. All in all, it is worth mentioning here that $R_{d}$ may be affected by both excitation frequency and materials properties, and the seriousness of the perceived NFE can be different in various research studies.

The transmitted shear wave signals and the corresponding received ones for a bender element test on clean oven-dried Ottawa sand with $\sigma_{3}=300 \mathrm{kPa}$ and $\mathrm{e}_{0}=0.715$ under various frequencies $(4-20 \mathrm{kHz}$ ) have been provided in Fig. 5. For this purpose, a clean bender element specimen was prepared using dry tamping method as previously described, and experimented under confining pressure of $300 \mathrm{kPa}$ as the middle of the considered confinement range in this study (50-500 kPa). Additionally, excitation frequency of 4, 6, 8, 10, 12, 14, 16, 18, and $20 \mathrm{kHz}$ was selected in order to evaluate the influences of frequency on the BE results of clean ovendried Ottawa sand, and also to find the frequency/frequencies at which the most accurate shear wave travel time could be determined. As it can be clearly seen in Fig. 5, the first arrivals for the received signals almost placed in similar positions particularly for frequencies higher than 10 $\mathrm{kHz}$; however, the first arrival times in lower frequencies $(\leq 8 \mathrm{kHz})$ were obviously different. Furthermore, it should be said here that the presence of NFE in received signals were gradually weakened by increasing frequency which was in accordance with the relevant literature (Yamashita et al. 2009). Moreover, to validate the results of bender element tests on clean ovendried Ottawa sand and to confirm sample preparation/element configuration in this study, a resonant column test was conducted on a specimen of oven-dried Ottawa sand with identical void ratio $\left(e_{0}=0.715\right)$. The shear wave travel time measured by resonant column test for clean oven-dried Ottawa sand with $\sigma_{3}=300 \mathrm{kPa}$ and $\mathrm{e}_{0}=0.715$ has been also shown in Fig. 5 as a dotted line $\left(\mathrm{T}_{\text {Resonant column test }}=0.697 \mathrm{~ms}\right.$ ). It can be inferred from Fig. 5 that for higher frequencies 
$(\geq 10 \mathrm{kHz})$ there were an acceptable level of agreement between travel times determined by bender element and resonant column tests.

Having the comparable results obtained by a resonant column test on clean oven-dried Ottawa sand, it is logical at this step to concentrate on the methods determining shear wave travel time in bender element tests with the aim of selecting the most accurate methods for further investigations in this study. Generally speaking, in the relevant literature, several methods were proposed to find shear wave travel time which can be totally grouped as temporal, mathematical, and frequency methods. Temporal methods are based on user's capability to appropriately make particular marks (peaks and first arrivals) on signals of transmitted and received waves and to precisely calculate various shear wave travel times such as start-to-start $\left(\mathrm{T}_{\mathrm{ss}}\right)$ and peak-to-peak $\left(\mathrm{T}_{\mathrm{pp}}\right)$. Due to different travel times measured by temporal methods, an alternative mathematical method (cross-correlation function) has been also proposed. This method was firstly developed by Viggiani and Atkinson in 1995 in order to analyze the results of bender element tests based on the original mathematical procedure employed by Mancuso et al. in 1989 for evaluation of crosshole test results (Mancuso et al. 1989; Viggiani and Atkinson 1995). Based on the experimental study conducted by Viggiani and Atkinson and confirmed by the subsequent relevant research studies (Arulnathan et al. 1998; Jovičić et al. 1996; Kawaguchi et al. 2001; Kumar and Madhusudhan 2010; Lee and Santamarina 2005; Leong et al. 2009; Murillo et al. 2011), the time corresponding to maximum of cross-correlation function $\left(\mathrm{T}_{\mathrm{cc}}\right)$ which must be applied to transmitted and received wave signals may be correct shear wave travel time. In Fig. 6, transmitted shear wave and its received signals as well as the curve of cross-correlation function have been provided for clean oven-dried Ottawa sand under $\sigma_{3}=50 \mathrm{kPa}$ and at frequency of 50 $\mathrm{kHz}$ as a simple example. To determine shear wave travel time based on temporal methods, 
particular points on both transmitted and received signals were distinguished including A and B on input shear wave, $\mathrm{C}$ on cross-correlation curve, and D, E, F, and G on output wave. According to these markers, several start-to-start travel times such as $\mathrm{T}_{\mathrm{AD}}, \mathrm{T}_{\mathrm{AE}}, \mathrm{T}_{\mathrm{AF}}$, and $\mathrm{T}_{\mathrm{AG}}$, one peak-to-peak travel time $\left(\mathrm{T}_{\mathrm{BG}}\right)$ as well as $\mathrm{T}_{\mathrm{cc}}$ based on the peak of cross-correlation function can be introduced. Precisely speaking, all of start-to-start travel times $\left(\mathrm{T}_{\mathrm{AD}}, \mathrm{T}_{\mathrm{AE}}\right.$, and $\left.\mathrm{T}_{\mathrm{AF}}\right)$ can be a possible shear wave travel time; however, due to results of resonant column tests the points of D and E which may be influenced by the NFE cannot be selected as an accurate shear wave travel time. Therefore, hereafter $\mathrm{T}_{\mathrm{AF}}, \mathrm{T}_{\mathrm{BG}}$, and $\mathrm{T}_{\mathrm{cc}}$ should be considered to find the best and most accurate shear wave travel time in BE tests. In this regard, shear wave travel time measured by temporal methods (start-to-start (SS) and peak-to-peak (PP)) and mathematical method (CC) were illustrated in Fig. 7 for oven-dried Ottawa sand $\left(e_{0}=0.715\right)$ under different confining pressure $(100,200,300,400$, and $500 \mathrm{kPa})$ and various excitation frequencies $(2,4,6,8,10,12$, 14, 16, 18, and $20 \mathrm{kHz}$ ). It can be clearly seen that, for frequencies higher than $8 \mathrm{kHz}$, an agreement can be found among shear wave travel time measured by temporal and mathematical method. However, the data of waves travelled by a frequency of 2 and $4 \mathrm{kHz}$ are almost different from the others, and they cannot be considered for further investigation in this research. In addition, shear wave travel time obtained by RC test under confining pressure of 100, 300, and $500 \mathrm{kPa}$ have been also shown in Fig. 7, and it can be seen that the agreement between the BE and $\mathrm{RC}$ results is approximately available for frequencies higher than $10 \mathrm{kHz}$. However, for the most part, shear wave travel time measured by BE system were slightly lower than those determined by RC device. Additionally, in a more precise way, shear wave travel time determined by BE tests on clean oven-dried Ottawa sand with void ratio of 0.715 have been depicted in Fig. 8 under different confining pressure (100-500 kPa) and excitation frequencies 
$(2-20 \mathrm{kHz})$. As it was previously pointed, the agreement between temporal and mathematical method as well as resonant column test was also observable in Fig. 8 for higher frequencies, especially for frequencies greater than $10 \mathrm{kHz}$ (marked as consistency range). In addition, all frequencies within the proposed consistency range (Fig. 8) can meet the suggested critical value for $\mathrm{R}_{\mathrm{d}}$ (Arroyo et al. 2006; Brignoli et al. 1996; Jovičić et al. 1996; Leong et al. 2009; Presti et al. 1997; Sanchez-Salinero 1987). As an overall analysis and due to the appropriate agreement among start-to-start, cross-correlation, and RC travel times, start-to-start and cross-correlation travel time were used for determining shear wave travel time hereafter in this study.

\subsection{Microstructure of crude oil contaminated Ottawa sand}

In Fig. 9 and Fig. 10, it was tried to precisely consider influences of crude oil contamination on surface roughness of sand grains and also on interlocking circumstances among sand particles by comparing SEM images of both clean and contaminated Ottawa sand with 4, 8, and 12 wt.\% of crude oil content as an example captured by a scanning electron microscopy apparatus (KYKY EM3200, China). As it can be apparently observed in Fig. 9 (a and b), uniformly adding 4 wt.\% of crude oil into the clean Ottawa sand made clear-cut changes on both surface roughness and interlocking of sand particles so that a significant part of space between particles (surrounding contact areas) was filled by hydrocarbon compounds so that this positioning may be an influential factor increasing cohesion among sand particles. On the other hand, although the presence of 4 wt.\% of crude oil onto sand particle surface is obvious in Fig. 9(b), its amount seems not to be effective enough to lessen the surface roughness of grains, so both cohesion and friction can be probable among sand particles. Having increased amount of crude oil contamination up to 8 and 12 wt.\% which can be respectively seen in Fig. 9(c) and Fig. 9(d), the 
space among particles are almost filled completely by hydrocarbon compounds, and additionally the surface roughness is almost smeared by a layer of crude oil. Generally speaking, obvious differences which are observed in interlocking and roughness of contaminated sand particles with varied amounts of contamination may be led to various macroscale responses of oil contaminated sand specimens to wave propagation phenomenon so that $4 \mathrm{wt} . \%$ contaminated sample seems to have a far more connected structure rather than both clean and other contaminated specimens ( 8 and 12 wt.\%). These explained observation can be also investigated by use of SEM images with magnification of 250X provided in Fig. 10.

\subsection{Shear wave velocity in crude oil contaminated Ottawa Sand}

This section is aimed at examining influences of light crude oil contamination on shear wave velocity of Ottawa sand. In this regard, shear wave velocity of clean and crude oil contaminated Ottawa sand with crude oil content of 4, 6, 8, 10, and 12 wt.\% have been presented in Fig. 11. For this purpose, a series of bender element tests has been conducted under confining pressure of $100,200,300,400$, and $500 \mathrm{kPa}$ and at frequency of $10 \mathrm{kHz}$ as an amount within the proposed consistency range. According to the results, it can be stated that increasing the level of confinement prominently increased shear wave velocity in both clean and crude oil contaminated samples. This trend is a well-known observation in findings of bender element tests conducted on clean sandy soils (Cai et al. 2015; Dyvik and Madshus 1986; Leong et al. 2009; Yamashita et al. 2009). To add to that, according to research findings in the present paper, increasing confining pressure can grow shear wave velocity of hydrocarbon-contaminated sand so that the tendency of alterations was almost similar for all percentages of crude oil contamination. Moreover, the serious of confinement-induced changes in shear wave velocity of contaminated 
sand is slightly diminished as confining pressure increased, and this process was approximately seen in clean specimens (Fig, 11). These observations can be associated with this fact that in lower amounts of confinement it can be possible for sand particles to move into soil pores forming a much more compacted skeleton; however, in higher confining pressure this possibility is gradually going to be weakened. Precisely speaking, it can be imaginable at the first glance in hydrocarbon-contaminated sands that influences of hydrocarbon compounds on confininginduced changes in shear wave velocity is higher in comparison with clean sand as result of lubricant effects of contaminant in inter-particles situations, but distinguishable differences were not observed in how clean and contaminated specimens reacted to increasing confining pressure (Fig. 11). The authors believed that hydrocarbon-induced cohesion among sand particles may be responsible to control lubricant effects of hydrocarbon contaminants in sand skeleton such that resultant response was approximately similar to clean sand samples in terms of hydrocarbon contamination.

More importantly, it should be mentioned that 4 wt. $\%$ contaminated specimens presented the highest velocities among all samples, and surprisingly there were not significant differences between wave velocities of all $6,8,10$, and $12 \mathrm{wt} . \%$ contaminated specimens. In addition, under each confining pressure, shear wave velocity of clean Ottawa sand was greater than that of all 6 , 8, 10, and 12 wt. $\%$ contaminated Ottawa sand samples. In general, these observations can be associated with the microstructure investigations into crude oil contaminated Ottawa sand. Based on SEM observation, it is probable that addition of crude oil contamination into sand structure up to 4 wt.\% may trigger positive influences on cohesive and frictional behavior of Ottawa sand, thereby forming a more connected structure within the sand skeleton to facilitate shear waves to propagate into sand skeleton. However, adding more contaminants into sand samples (6-12 

were not considerable changes in shear wave velocity of contaminated samples with higher amount of contamination (6-12 wt.\%), and additionally these samples showed shear wave velocities which were slightly lower than clean sand samples under all confining pressures. It should be mentioned here that these observations may be related to the opposite effects of adding more contamination ( $\geq 4 \mathrm{wt} . \%)$ in sand skeleton causing an increase in inter-particle cohesion and a decrease in inter-particle friction which could result in approximately unchanged trend. With a precise look at microstructure characteristics of contaminated sand in Fig. 9 and 10, the authors believe that, in the case of 4 wt.\% contaminated Ottawa sand, both roughness and hydrocarboninduced cohesion among sand particles were dominant in inter-particle relationships to form better contacts among sand particles and to provide appropriate wave paths for shear wave signals to propagate into $4 \mathrm{wt} \%$ contaminated sand sample. However, adding more crude oil into sand (6-12 wt.\%) could cause significant negative effects on contacts among sand particles so that a majority of space among grain was filled with hydrocarbon compounds to some extend that there was a complex situation for shear wave signals to transmit through sand particles coated with a thick hydrocarbon layer. As a further point to be considered in the results, it should be mentioned that adding light crude oil contamination into sand structure could gradually increase shear wave velocity up to $4 \mathrm{wt} . \%$ in which the highest value of shear wave velocity was recorded. It seems that 4 wt.\% of crude oil can be defined as a critical value in this research so that passing this value could cause negative effects on shear wave velocity. In addition, adding crude oil, from 4 to 6 wt.\%, could cause significant influences on inter-particle situations of sand skeleton such that shear wave velocity of $6 \mathrm{wt} \%$ contaminated sand were lower than that of clean sand under all confinement levels. In other words, significant changes were made in inter- 
particle circumstances of contaminated Ottawa sand when the content of light crude oil increased from 4 to $6 \mathrm{wt} . \%$, and beyond this range there was no noticeable alteration to be mentioned.

Precisely speaking, the effects of increasing crude oil contamination on shear wave velocities of Ottawa sand have been also illustrated in Fig. 12 under various confining pressure at frequency of $10 \mathrm{kHz}$. According to data provided, increasing crude oil content up to $4 \mathrm{wt} \%$ in clean sample could substantially increase shear wave velocity about 1.16 times for $\sigma_{3}=500 \mathrm{kPa}$ and 1.2 times for $\sigma_{3}=100 \mathrm{kPa}$. It can be said that, under higher confining pressures, the influences of contamination on shear wave velocity might be slightly weakened, especially for higher amounts of contaminants such as 8, 10, 12 wt.\% (see also Fig. 11). However, increasing this type of hydrocarbon contamination from 4 to $6 \mathrm{wt} . \%$ made an apparent reduction in the value of shear wave velocity so that, almost under all confining pressures, shear wave velocity of 6 wt. $\%$

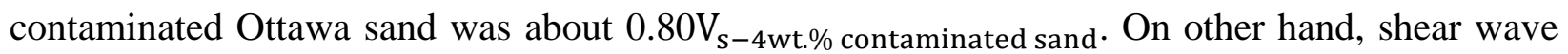
velocity of $6 \mathrm{wt} \%$ contaminated Ottawa sand was slightly lower than that of the clean sand $\left(0.95-0.97 \mathrm{~V}_{\mathrm{s}-\text { clean Ottawa sand }}\right)$. It should be added here that adding farther amounts of crude oil ( $\geq 6$ wt.\%) did not make significant changes in shear wave velocity.

\section{Conclusion}

This study was aimed at experimentally examining influences of light crude oil contamination on shear wave velocity of Ottawa sand using a bender element system. In this connection, all clean and contaminated sand specimens were similarly prepared using dry and quasi-tamping method, respectively. In order to distinguish the most accurate methods of determining shear wave travel time in BE tests, both bender element and resonant column test were separately conducted on clean oven-dried Ottawa sand with identical specifications. In this regard, each BE test was 
conducted at several excitation frequencies $(2-20 \mathrm{kHz})$ and under different confining pressures (50-500 kPa). In this research, light crude oil was considered as hydrocarbon contamination, and oven-dried Ottawa sand were thoroughly mixed with $4,6,8,10$, and 12 wt.\% of crude oil to prepare contaminated samples. To sum up, the main conclusions of this study have been outlined as follows:

(1) Based on the results of bender element and resonant column tests which were conducted on similarly prepared specimens of oven-dried clean Ottawa sand (with an identical void ratio), it was concluded in this research that peak-to-peak, start-to-start, and crosscorrelation methods were the most accurate and reliable techniques determining shear wave travel time.

(2) The shear wave travel time measured by bender element system for clean dry Ottawa sand have been greatly influenced by lower excitation frequencies $(\leq 8 \mathrm{kHz})$, and the effectiveness of frequency on travel time were significantly alleviated at higher frequencies (consistency range). Thus, in this study, it was deduced that bender element test should be conducted in higher frequencies $(10-20 \mathrm{kHz})$ as a consistency range.

(3) According to BE results of crude oil contaminated sand, it can be inferred that there was a critical content of crude oil ( $4 \mathrm{wt} . \%$ in this research) so that the highest value of shear wave velocity was available at this particular content. Moreover, increasing crude oil content in sand up to this critical value grew shear wave velocity, and adding further oil caused significant negative effects on shear wave velocity. In this regard, it should be mentioned that adding further crude oil up to $6 \mathrm{wt} . \%$ made a considerable change, and shear wave velocity of 6 wt.\% contaminated Ottawa sand was about

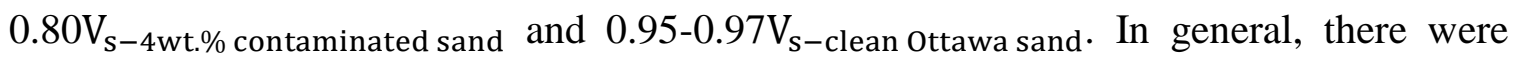


not obvious changes in amounts of shear wave velocity of Ottawa sand samples with crude oil contamination higher than 6 wt.\% (6-12 wt.\%).

(4) It was tried in this study to carefully execute all steps of research and to effectively alleviate sources of uncertainties; however, a few conditions were out of complete researchers' control such as system delay. In order to fairly consider the system delay, the delay time have been measured by direct contact of the bender elements at different frequencies and considered in the calculations. Moreover, hydrocarbon-induced changes in shear wave velocity of natural sand can be proposed for the future studies, and also it would be beneficial to use other kinds of hydrocarbon compounds as contaminants.

\section{Acknowledgment}

The authors wish to greatly acknowledge the beneficial supports in doing this research provided by West Oil and Gas Production Company (WOGPC) of Iran, Soil Mechanics Industry of Iran (SMI), and also International Institute of Earthquake Engineering and Seismology of Iran (IIEES).

\section{References}

Aiban SA (1998) The Long-term Environmental Effects of the Gulf WarThe effect of temperature on the engineering properties of oil-contaminated sands Environment International 24:153-161 doi:http://dx.doi.org/10.1016/S0160-4120(97)00131-1

Akinwumi II, Diwa D, Obianigwe N (2014a) Effects of crude oil contamination on the index properties, strength and permeability of lateritic clay Internationla Journal of Applied Sciences and Engineering Research 3:816-824 
Akinwumi II, Maiyaki UR, Adubi SA, Daramola SO, Ekanem BB (2014b) Effects of waste engine oil contamination on the plasticity, strength and permeability of lateritic clay International Journal of Scientific \& Technology Reseaech 3:331-335

Al-Sanad HA, Eid WK, Ismael NF (1995) Geotechnical Properties of Oil-Contaminated Kuwaiti Sand Journal of Geotechnical Engineering 121:407-412 doi:doi:10.1061/(ASCE)07339410(1995)121:5(407)

Al-Sanad HA, Ismael NF (1997) Aging Effects on Oil-Contaminated Kuwaiti Sand Journal of Geotechnical and Geoenvironmental Engineering 123:290-293 doi:10.1061/(ASCE)10900241(1997)123:3(290)

Alhassan HM, Fagge SA (2013) Effects of crude Oil, low point pour fuel oil and vacuum gas oil contamination on the geotechnical properties sand, clay and laterite soils International Journal of Engineering Research and Applications 3:1947-1954

Arroyo M, Wood DM, Greening PD, Medina L, Rio J (2006) Effects of sample size on benderbased axial G0 measurements Géotechnique 56:39-52 doi:10.1680/geot.2006.56.1.39

Arulnathan R, Boulanger R, Riemer M (1998) Analysis of Bender Element Tests

ASTM (2009) Standard Specification for Standard Sand vol C 778. ASTM International,, West Conshohocken, PA, 2013

Brignoli E, Gotti M, Stokoe K (1996) Measurement of Shear Waves in Laboratory Specimens by Means of Piezoelectric Transducers Geotechnical Testing Journal 19:384-397 doi:10.1520/GTJ10716J

Budhu M, Giese Jr RF, Campbell G, Baumgrass L (1991) The permeability of soils with organic fluids Canadian Geotechnical Journal 28:140-147 doi:10.1139/t91-015 
Cai Y, Dong Q, Wang J, Gu C, Xu C (2015) Measurement of small strain shear modulus of clean and natural sands in saturated condition using bender element test Soil Dynamics and Earthquake Engineering 76:100-110 doi:10.1016/j.soildyn.2014.12.013

Castelli F, Cavallaro A, Grasso S, Lentini V (2016) Seismic microzoning from synthetic ground motion earthquake scenarios parameters: The case study of the city of Catania (Italy) Soil Dynamics and Earthquake Engineering 88:307-327 doi:10.1016/j.soildyn.2016.07.010 Cavallaro A, Ferraro A, Grasso S, Maugeri M (2012) Topographic effects on the Monte Po Hill in Catania (Italy) Soil Dynamics and Earthquake Engineering 43:97-113 doi:10.1016/j.soildyn.2012.07.022

Cavallaro A, Grasso S, Maugeri M, Motta E (2013a) An innovative low-cost SDMT marine investigation for the evaluation of the liquefaction potential in the Genova Harbour, Italy. In: Coutinho RQ, Mayne PW (eds) Geotechnical and Geophysical Site Characterization 4. Taylor \& Francis Group, London, pp 637-644

Cavallaro A, Grasso S, Maugeri M, Motta E (2013b) Site characterisation by in situ and laboratory tests of the sea bed in the Genova Harbour, Italy. In: Geotechnical and Geophysical Site Characterization 4. CRC Press, pp 415-422. doi:10.1201/b13251-44

Cook EE, Puri VK, Shin EC (1992) Geotechnical Characteristics Of Crude Oil-Contaminated Sands. Paper presented at the The Second International Offshore and Polar Engineering Conference, San Francisco, California, USA,

Di Matteo L, Bigotti F, Ricco R (2011) Compressibility of Kaolinitic Clay Contaminated by Ethanol-Gasoline Blends Journal of Geotechnical and Geoenvironmental Engineering 137:846-849 doi:10.1061/(ASCE)GT.1943-5606.0000494 
Dyvik R, Madshus C Lab Measurements of Gmax Using Bender Element. In: Proc. ASCE convention on Advances in the art of testing soils under cyclic conditions, 1986. pp 186196

Estabragh AR, Beytolahpour I, Moradi M, Javadi AA (2016) Mechanical behavior of a clay soil contaminated with glycerol and ethanol European Journal of Environmental and Civil Engineering 20:503-519 doi:10.1080/19648189.2015.1047900

Evgin E, Das BM Mechanical behavior of an oil contaminated sand. In: Acar. Ua (ed) Envir. Geotechnol., Proc., Mediterranean Conf., Rotterdam. The Netherlands, 1992. Balkema Publishers, pp 101-108

Foreman DE, Daniel DE (1986) Permeation of Compacted Clay with Organic Chemicals Journal of Geotechnical Engineering 112:669-681 doi:doi:10.1061/(ASCE)07339410(1986)112:7(669)

Grasso S, Maugeri M (2014) Seismic microzonation studies for the city of Ragusa (Italy) Soil Dynamics and Earthquake Engineering 56:86-97

doi:http://dx.doi.org/10.1016/j.soildyn.2013.10.004

Gu X, Yang J, Huang M (2013) Laboratory measurements of small strain properties of dry sands by bender element Soils and Foundations 53:735-745 doi:http://dx.doi.org/10.1016/j.sandf.2013.08.011

Ijimdiya TS (2013) The Effects of Oil Contamination on the Consolidation Properties of Lateritic Soil Development and Applications of Oceanic Engineering (DAOE) 2:53-59 Jia YG, Wu Q, Meng X, Yang X, Yang Z, Zhang G (2010) Case Study on Influences of Oil Contamination on Geotechnical Properties of Coastal Sediments in The Yellow River Delta. In: Chen Y, Zhan L, Tang X (eds) Advances in Environmental Geotechnics: 
Proceedings of the International Symposium on Geoenvironmental Engineering in Hangzhou, China, September 8-10, 2009. Springer Berlin Heidelberg, Berlin, Heidelberg, pp 767-771. doi:10.1007/978-3-642-04460-1_94

Jovičić V, Coop MR, Simić M (1996) Objective criteria for determining Gmax from bender element tests Géotechnique 46:357-362 doi:10.1680/geot.1996.46.2.357

Kawaguchi T, Mitachi T, Shibuya S (2001) Evaluation of shear wave travel time in laboratory by bender element test. Paper presented at the The Fifteenth International Conference on Soil Mechanics and Geotechnical Engineering, Istanbul,

Kermani M, Ebadi T (2012) The Effect of Oil Contamination on the Geotechnical Properties of Fine-Grained Soils Soil and Sediment Contamination: An International Journal 21:655-671 doi:10.1080/15320383.2012.672486

Khamehchiyan M, Hossein Charkhabi A, Tajik M (2007) Effects of crude oil contamination on geotechnical properties of clayey and sandy soils Engineering Geology 89:220-229 doi:http://dx.doi.org/10.1016/j.enggeo.2006.10.009

Khosravi E, Ghasemzadeh H, Sabour MR, Yazdani H (2013) Geotechnical properties of gas oilcontaminated kaolinite Engineering Geology 166:11-16 doi:http://dx.doi.org/10.1016/j.enggeo.2013.08.004

Kumar J, Madhusudhan BN (2010) A note on the measurement of travel times using bender and extender elements Soil Dynamics and Earthquake Engineering 30:630-634 doi:http://dx.doi.org/10.1016/j.soildyn.2010.02.003

Lee J-S, Santamarina JC (2005) Bender Elements: Performance and Signal Interpretation Journal of Geotechnical and Geoenvironmental Engineering 131:1063-1070 doi:10.1061/(ASCE)1090-0241(2005)131:9(1063) 
Leong EC, Cahyadi J, Rahardjo H (2009) Measuring shear and compression wave velocities of soil using bender-extender elements Canadian Geotechnical Journal 46:792-812 doi:10.1139/T09-026

Ling SY, Yong LC (2013) Behavior of piles in palm biodiesel contaminated mining sand International journal of environmental science 3:1822-1830

Mancuso C, Simonelli AL, Vinale F (1989) Numerical analysis of in situ S-wave measurements. Paper presented at the Proc 12th International Conference on Soil Mechanics and. Foundation Engineering, Rio de Janeiro,

Maugeri M, Grasso S (2013) Liquefaction potential evaluation at Catania Harbour (Italy). In: Brebbia CA, Hernández S (eds) Earthquake Resistant Engineering Structures IX, vol 132. WIT Press, WIT Transactions on The Built Environment, pp 69-82. doi:10.2495/ERES130061

Meegoda J, Rajapakse RA (1993) Short-Term and Long-Term Permeabilities of Contaminated Clays Journal of Environmental Engineering 119:725-743 doi:doi:10.1061/(ASCE)07339372(1993)119:4(725)

Meegoda J, Ratnaweera P (1994) Compressibility of contaminated fine-grained soils Geotechnical Testing Journal 17:101-112 doi:10.1520/GTJ10078J

Mirsal IA (2004) Soil Pollution Origin, Monitoring \& Remediation. Springer, Germany Murillo C, Sharifipour M, Caicedo B, Thorel LUC, Dano C (2011) Elastic parameters of intermediate soils based on bender-extender element pulse tests Soils and Foundation 51:637-649 doi:10.3208/sandf.51.637 
Naeini SA, Shojaedin MM (2014) Effect of oil contamination on the liquefaction behavior of sandy soils International Journal of Environmental, Chemical, Ecological, Geological and Geophysical Engineering 8:289-292

Nasr AMA (2013) Uplift Behavior of Vertical Piles Embedded in Oil-Contaminated Sand Journal of Geotechnical and Geoenvironmental Engineering 139:162-174 doi:doi:10.1061/(ASCE)GT.1943-5606.0000739

Nazir AK (2011) Effect of motor oil contamination on geotechnical properties of over consolidated clay Alexandria Engineering Journal 50:331-335 doi:http://dx.doi.org/10.1016/j.aej.2011.05.002

Ochepo J, Joseph V (2014) Effect of oil contamination on lime stabilized soil Jordan Journal of Civil Engineering 8:88-96

Ola SA (1991) Geotechnical properties and behaviour of Nigerian tar sand Engineering Geology 30:325-336 doi:http://dx.doi.org/10.1016/0013-7952(91)90066-T

Onyelowe KC (2015) Pure crude oil contamination on Amaoba lateritic soil The Electronic Journal of Geotechnical Engineering (EJGE) 20:1129-1142

Oyegbile OB, Ayininuola GM (2013) Laboratory Studies on the Influence of Crude Oil Spillage on Lateritic SoilShear Strength: A Case Study of Niger Delta Area of Nigeria Journal of Earth Sciences and Geotechnical Engineering 3:73-83

Presti DCFL, Jamiolkowski M, Pallara O, Cavallaro A, Pedroni S (1997) Shear modulus and damping of soils Géotechnique 47:603-617 doi:10.1680/geot.1997.47.3.603

Puri VK (2000) Geotechnical Aspects of Oil-Contaminated Sands Journal of Soil Contamination 9:359-374 doi:10.1080/10588330091134301 
Puri VK, Das BM, Cook EE, Shin EC (1994) Geotechnical Properties of Crude Oil Contaminated Sand. doi:10.1520/STP12658S

Pusadkar SS, Bharambe PS (2014) Performance of petrol and diesel contaminated black cotton soil International Journal of Engineering Research \& Technology (IJERT) 3:536-539

Rahman H, Abduljauwad SN, Akram SN (2007) Geotechnical Behavior of Oil-Contaminated Fine-Grained Soils Electronic Journal of Geotechnical Engineering 12:Paper 0720 doi:http://www.ejge.com/2007/Ppr0720/Ppr0720.htm

Rahman ZA, Hamzah U, Ahmad N (2010a) Geotechnical Characteristics of Oil-Contaminated Granitic and Metasedimentary Soils Asian Journal of Applied Sciences 3:237-249 doi:10.3923/ajaps.2010.237.249

Rahman ZA, Hamzah U, Taha MR, Ithnain NS, Ahmad N (2010b) Influence of Oil Contamination on Geotechnical Properties of Basaltic Residual Soil American Journal of Applied Sciences 7:8 doi:10.3844/ajassp.2010.954.961

Sanchez-Salinero I (1987) Analytical investigation of seismic methods used for engineering application. The University of Texas at Austin, Austin, Texas

Shin EC, Das BM (2001) Bearing Capacity of Unsaturated Oil-Contaminated Sand International Journal of Offshore and Polar Engineering 11:220-226

Shin EC, Lee JB, Das BM (1999) Bearing Capacity of a Model Scale Footing on Crude OilContaminated Sand Geotechnical \& Geological Engineering 17:123-132 doi:10.1023/a:1016078420298

Shin EC, Omar MT, Tahmaz AA, Das BM Shear strength and hydraulic conductivity of oilcontaminated sand. In: L.G. de Mello MA (ed) Proceedings of the Fourth International 
Congress on Environmental Geotechnics,, Rio de Janeiro, Brazil, 2002. A.A. Balkema Publishers, Lisse,, pp 9-13

Siang AJLM, Wijeyesekera DC, Yahya SMAS, Ramlan M (2014) Innovative testing investigations on the influence of particle morphology and oil contamination on the geotechnical properties of sand International Journal of Integrated Engineering 6:60-66

Silvestri V, Mikhail N, Souli M (1997) Permeability Response of Oil-Contaminated Compacted Clays vol STP1275. ASTM doi:10.1520/STP1275-EB

Singh SK, Srivastava RK, John S (2008) Settlement Characteristics of Clayey Soils

Contaminated with Petroleum Hydrocarbons Soil and Sediment Contamination: An International Journal 17:290-300 doi:10.1080/15320380802007028

Singh SK, Srivastava RK, John S (2009) Studies on soil contamination due to used motor oil and its remediation Canadian Geotechnical Journal 46:1077-1083 doi:10.1139/T09-047

Solly G, Aswathy EA, Berlin S, Krishnaprabha NP, Maria G (2015) Study of geotechnical properties of diesel oil contaminated soil International Journal of Civil and Structural Engineering Research 2:113-117

Srivastava RK, Pandey VD Geotechnical evaluation of oil contaminated soil. In: Sarsby RW (ed) the proceeding of CREEN 2 in the second international symposium on Geotechnics Related to the Environment Krakow, Poland, 1997. Thomas Telford, London,

Talukdar DK, Saikia BD (2013) Effect of crude oil on some consolidation properties of clayey soil International Journal of Emerging Technology and Advanced Engineering 3:117-120

Tuncan A, Pamukcu S Geotechnical Properties of petroleum and sludge contaminatd marine sediments. In: the Second (1992) International Offshore and Polar Engineering Conference, 

Geotechnical Engineering 115:115-131 doi:doi:10.1061/(ASCE)07339410(1989)115:1(115)

Viggiani G, Atkinson JH (1995) Interpretation of bender element tests Géotechnique 45:149-154 doi:10.1680/geot.1995.45.1.149

Walia BS, Singh G, Kaur M (2013) Study of diesel contaminated clayey soil. Paper presented at the Proceedings of Indian Geotechnical Conference, Roorkee, India, December 22-24

Yamashita S, Kawaguchi T, Nakata Y, Mikami T, Fujiwara T, Shibuya S (2009) Interpretation of international parallel test on the measurement of Gmax using bender elements Soils and Foundation 49:631-650 doi:10.3208/sandf.49.631 


\section{List of Tables:}

Table 1. Basic properties of the used Ottawa sand and standard Ottawa sand (ASTM 2009)

Table 2. Chemical composition of the used Ottawa sand (provided by the supplier)

Table 3. Basic properties of the used light crude oil (supplied by WOGPC)

\section{List of Figures:}

Fig. 1. (a) Oven-dried Ottawa sand captured by a digital camera, (b, c, and d) SEM images of oven-dried Ottawa sand with different magnifications

Fig. 2. Particle size distribution curves of the used Ottawa sand in this study and graded Ottawa sand (ASTM 2009)

Fig. 3. (a) Digitally controlled triaxial apparatus (STRASSENTEST OHG, Germany) with an additional passive triaxial cell (SMI) (b) bender elements

Fig. 4. The delay times measured under the condition of straightforward tip-to-tip contacted bender elements at various frequencies

Fig. 5. Bender element test results on clean oven-dried Ottawa sand with $\sigma_{3}=300 \mathrm{kPa}$ and $\mathrm{e}_{0}=$ 0.715 at various amounts of excitation frequencies $(4,6,8,10,12,14,16,18$, and 20 $\mathrm{kHz})$

Fig. 6. Shear transmitted wave and its relevant received wave along with their resultant crosscorrelation curve for clean oven-dried Ottawa sand under $\sigma_{3}=50 \mathrm{kPa}\left(\mathrm{e}_{0}=0.715\right)$ and at frequency of $50 \mathrm{kHz}$

Fig. 7. Shear wave travel time (ms) measured by start-to-start (SS), peak-to-peak (PP), crosscorrelation (CC), and resonant column test $(\mathrm{RC})$ for oven-dried Ottawa sand $\left(\mathrm{e}_{0}=0.715\right)$ 
Fig. 8. Shear wave travel time (ms) measured by start-to-start $\left(T_{s s}\right)$, peak-to-peak $\left(T_{p p}\right)$, crosscorrelation $\left(\mathrm{T}_{\mathrm{cc}}\right)$, and resonant column test $\left(\mathrm{T}_{\mathrm{RC}}\right)$ for oven-dried Ottawa sand $\left(\mathrm{e}_{0}=0.715\right)$

Fig. 9. SEM images of (a) clean oven-dried Ottawa sand, (b) 4 wt.\% light crude oil contaminated Ottawa sand, (c) 8 wt.\% light crude oil contaminated Ottawa sand, and (d) 12 wt.\% light crude oil contaminated Ottawa sand captured at 26000 Volt with scale bar of 10 um and magnification of $1.00 \mathrm{KX}$

Fig. 10. SEM images of (a) clean oven-dried Ottawa sand, (b) 4 wt.\% light crude oil contaminated Ottawa sand, (c) 8 wt.\% light crude oil contaminated Ottawa sand, and (d) 12 wt. \% light crude oil contaminated Ottawa sand captured at 26000 Volt with scale bar of $10 \mathrm{um}$ and magnification of $250 \mathrm{X}$

Fig. 11. Shear wave velocity $(\mathrm{m} / \mathrm{s})$ of clean and contaminated Ottawa sand by various light crude oil contents (4-12 wt.\%) with $\mathrm{e}_{0}=0.715$ at frequency of $10 \mathrm{kHz}$ for different confining pressures

Fig. 12. Shear wave velocity $(\mathrm{m} / \mathrm{s})$ of clean and contaminated Ottawa sand by various light crude oil contents (4-12 wt.\%) with $\mathrm{e}_{0}=0.715$ at frequency of $10 \mathrm{kHz}$ for various amounts of contaminant 
Table 1. Basic properties of the used Ottawa sand and standard Ottawa sand (ASTM 2009),

\begin{tabular}{|l|c|c|c|c|c|c|}
\hline Sand type & $\mathrm{G}_{\mathrm{s}}$ & $\mathrm{D}_{10}$ & $\mathrm{D}_{30}$ & $\mathrm{D}_{60}$ & $\mathrm{C}_{\mathrm{u}}$ & $\mathrm{C}_{\mathrm{c}}$ \\
\hline Standard Ottawa (ASTM 2009) - upper limit & 2.65 & 0.234 & 0.314 & 0.397 & 1.696 & 1.059 \\
\hline The used Ottawa sand & 2.65 & 0.221 & 0.307 & 0.390 & 1.763 & 1.090 \\
\hline Standard Ottawa (ASTM 2009) - lower limit & 2.65 & 0.217 & 0.300 & 0.383 & 1.769 & 1.084 \\
\hline
\end{tabular}

Table 2. Chemical composition of the used Ottawa sand (provided by the supplier)

\begin{tabular}{|l|l|l|l|l|l|l|l|}
\hline Chemical compounds & $\mathrm{SiO}_{2}$ & $\mathrm{Fe}_{2} \mathrm{O}_{3}$ & $\mathrm{Al}_{2} \mathrm{O}_{3}$ & $\mathrm{k}_{2} \mathrm{O}$ & $\mathrm{CaO}$ & $\mathrm{MgO}$ & $\mathrm{Na}_{2} \mathrm{O}$ \\
\hline Percentage (wt.\%) & 97.48 & 0.45 & 0.95 & 0.39 & 0.27 & 0.24 & 0.22 \\
\hline
\end{tabular}

Table 3. Basic properties of the used light crude oil (supplied by WOGPC)

\begin{tabular}{|l|l|l|l|}
\hline Specific gravity & API & Salt $\left(\mathrm{gr} / \mathrm{m}^{3}\right)$ & $\mathrm{H}_{2} \mathrm{~S}$ (p. p. m) \\
\hline 0.888 & 28 & 34 & 22 \\
\hline
\end{tabular}


(a)
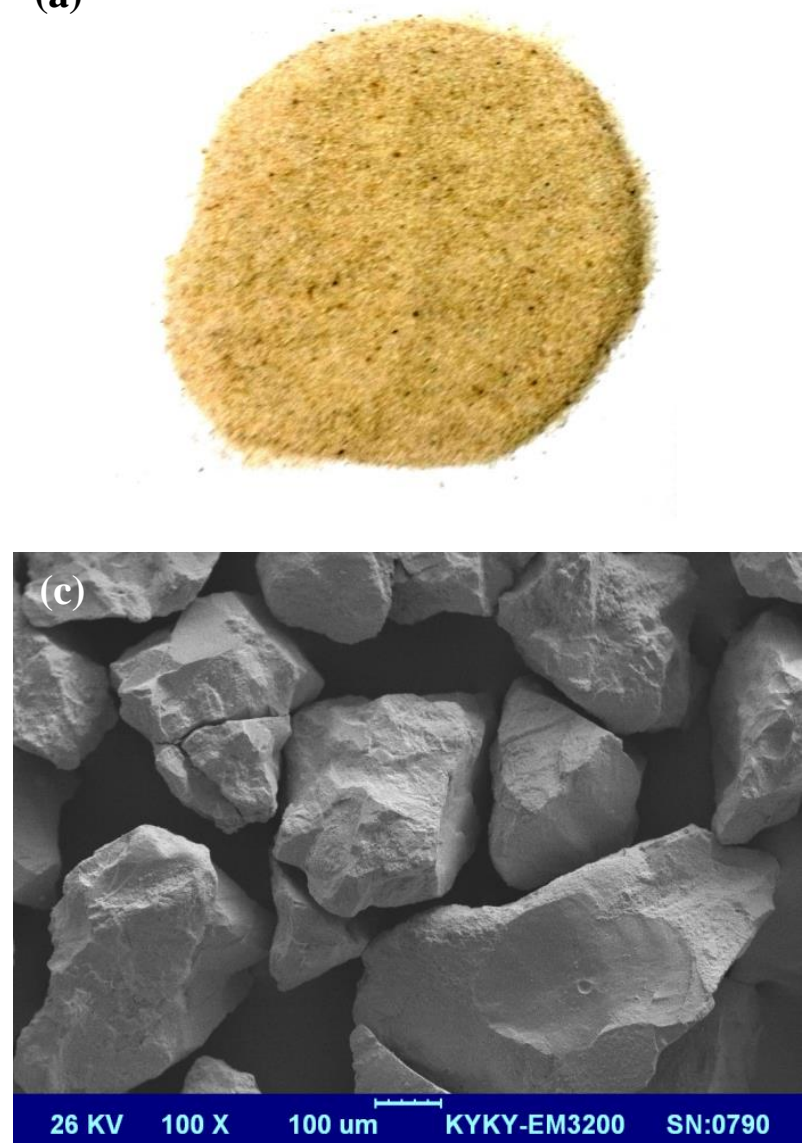
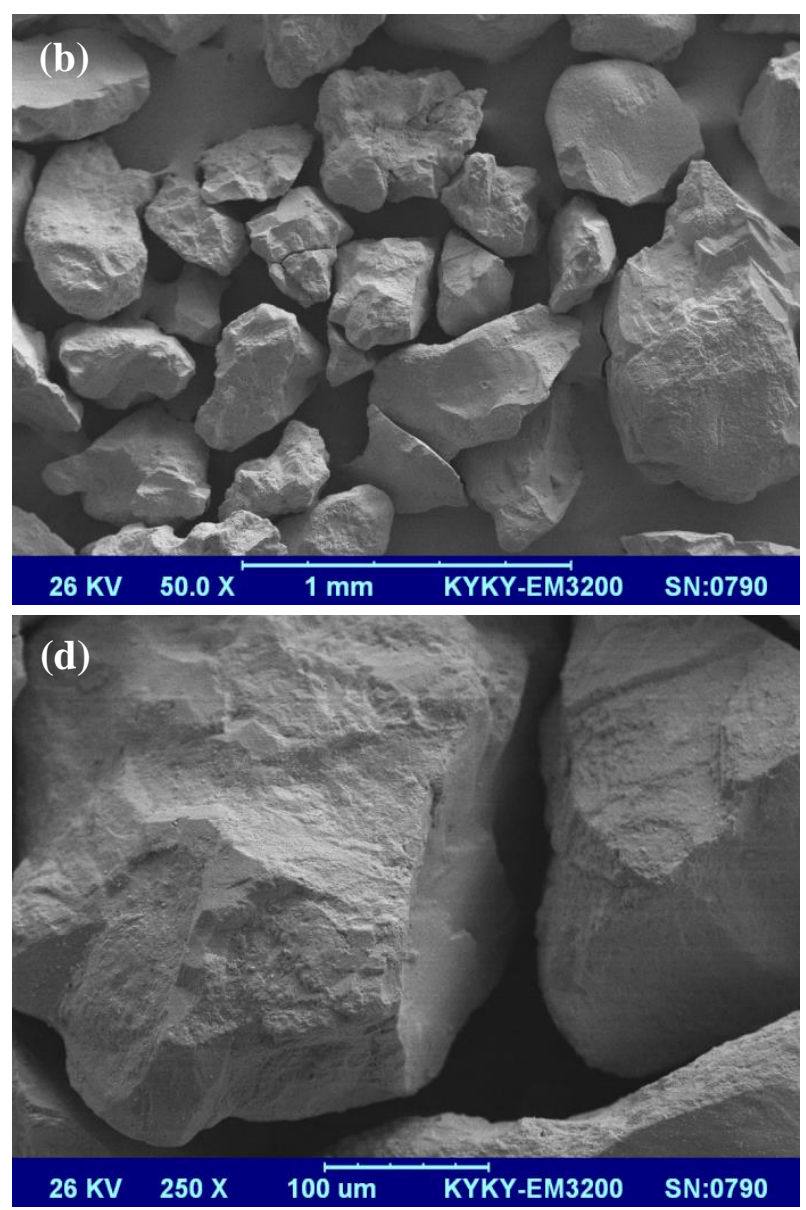

Fig. 1. (a) Oven-dried Ottawa sand captured by a digital camera, (b, c, and d) SEM images of oven-dried Ottawa sand with different magnifications 


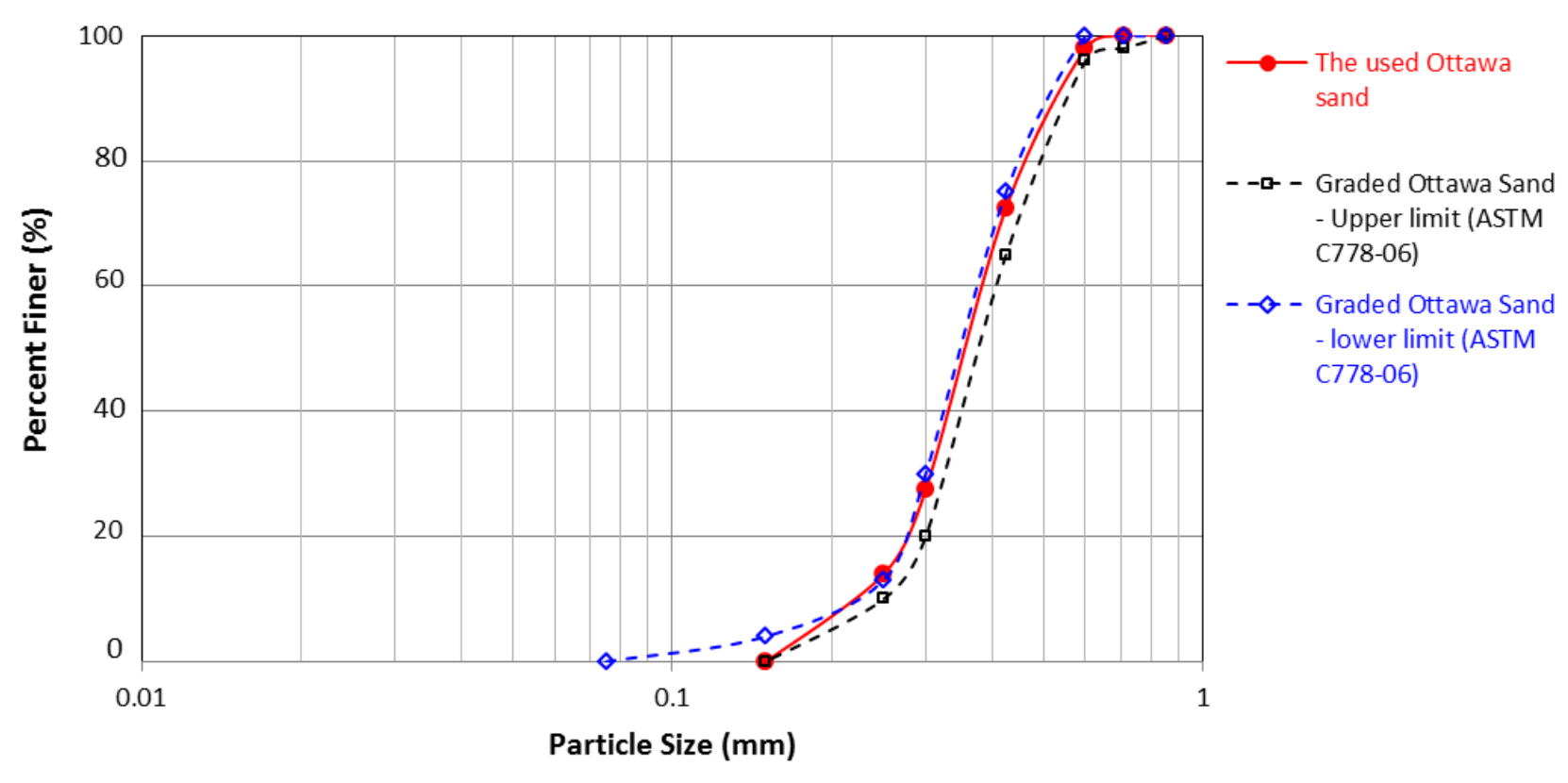

Fig. 2. Particle size distribution curves of the used Ottawa sand in this study and graded Ottawa sand (ASTM 2009) 


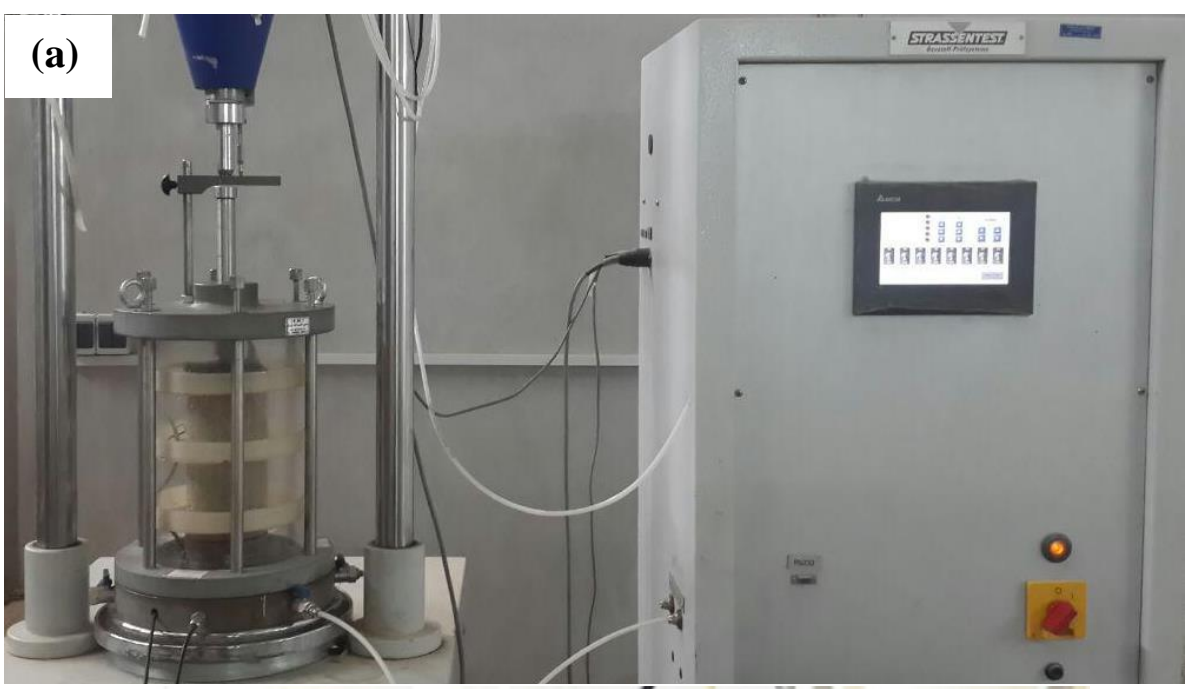

(b)

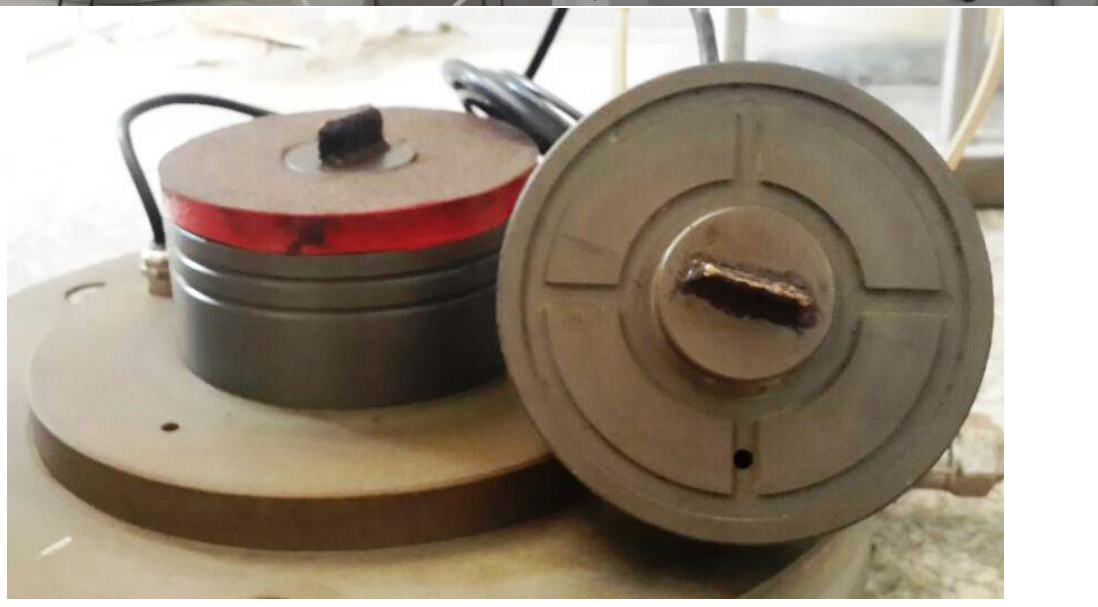

Fig. 3. (a) Digitally controlled triaxial apparatus (STRASSENTEST OHG, Germany) with an additional passive triaxial cell (SMI) (b) bender elements 


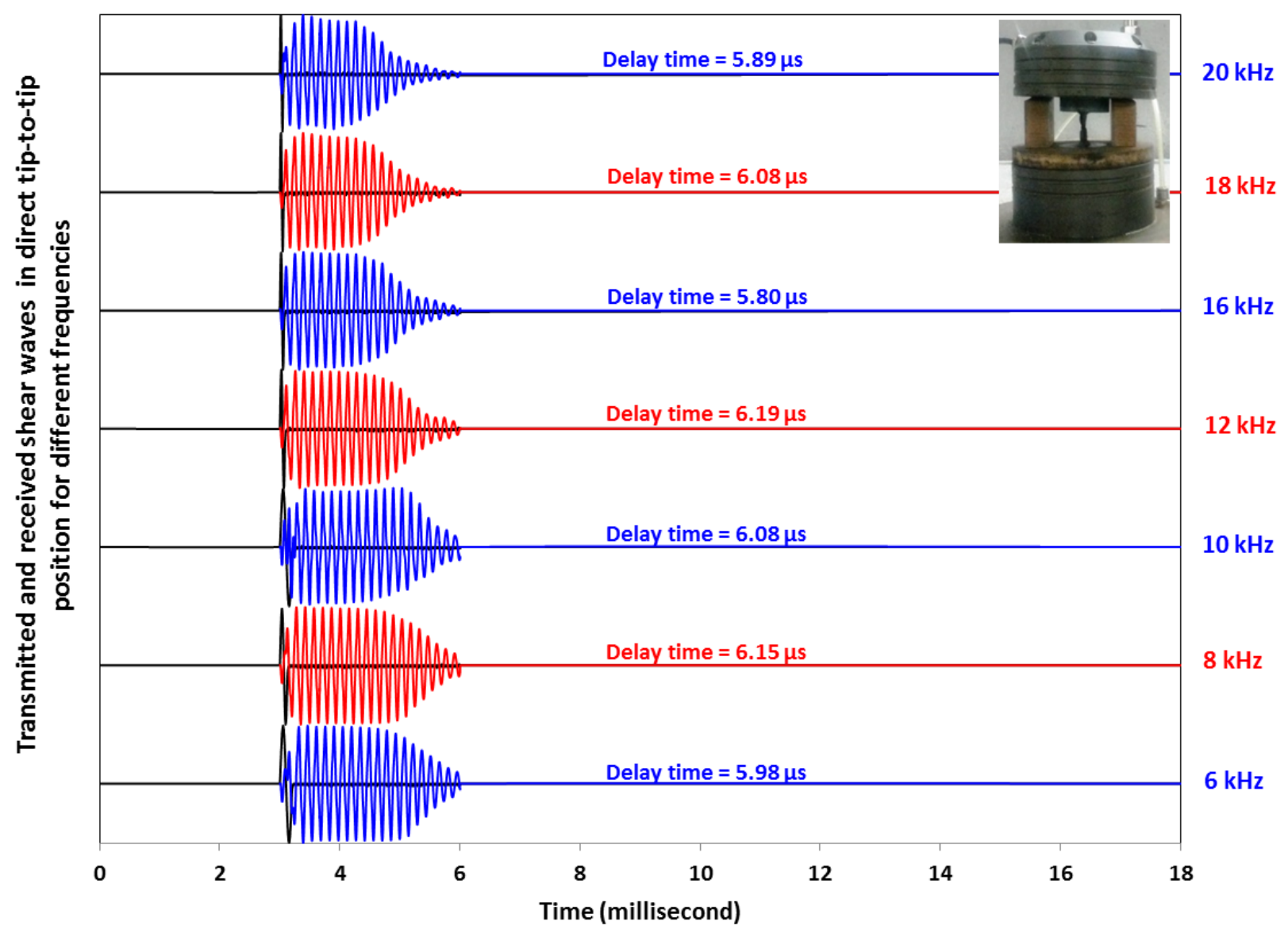

Fig. 4. The delay times measured under the condition of straightforward tip-to-tip contacted bender elements at various frequencies 


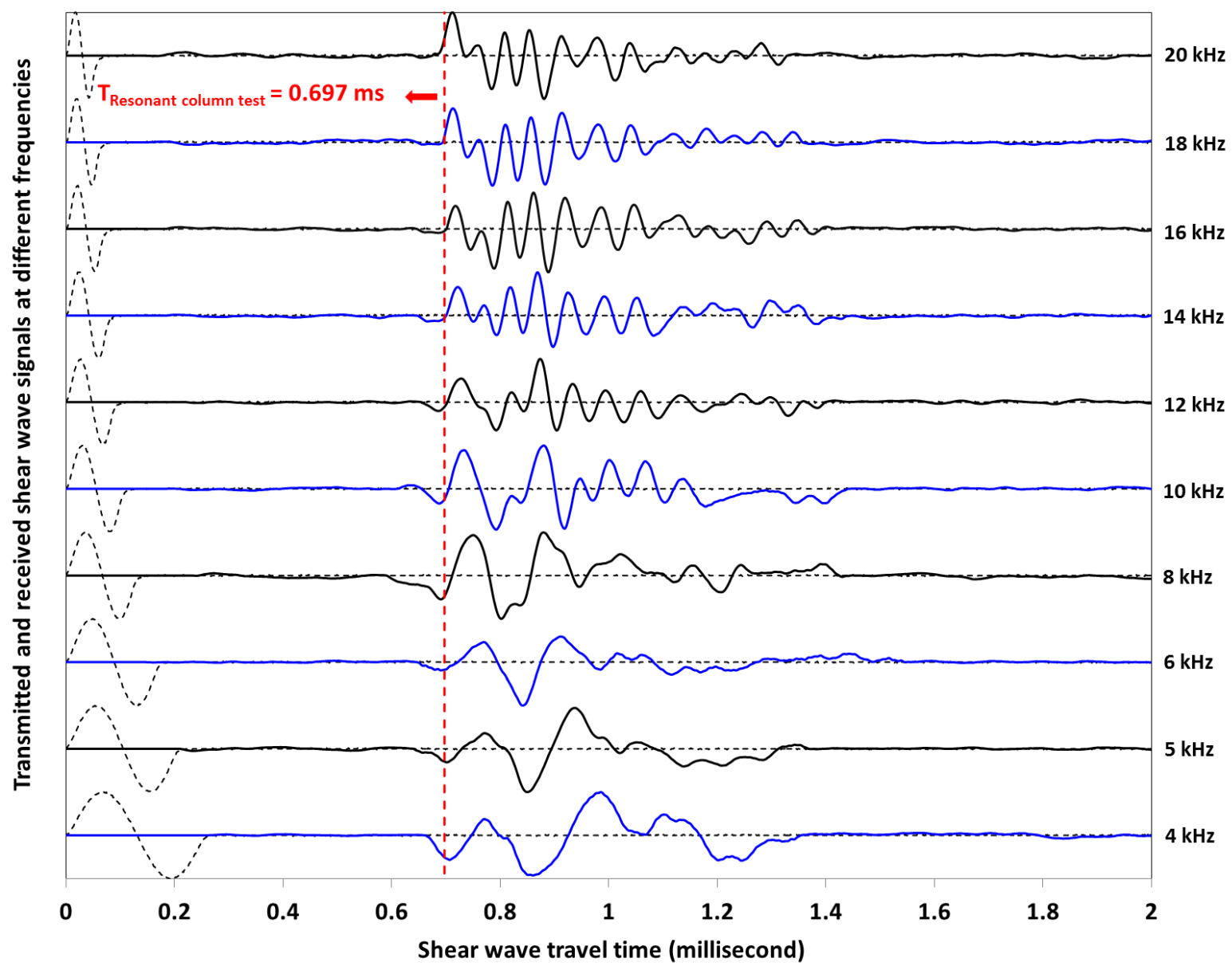

Fig. 5. Bender element test results on clean oven-dried Ottawa sand with $\sigma_{3}=300 \mathrm{kPa}$ and $\mathrm{e}_{0}=$ 0.715 at various amounts of excitation frequencies $(4,6,8,10,12,14,16,18$, and $20 \mathrm{kHz})$ 
Fig. 6. Shear transmitted wave and its relevant received wave along with their resultant crosscorrelation curve for clean oven-dried Ottawa sand under $\sigma_{3}=50 \mathrm{kPa}\left(\mathrm{e}_{0}=0.715\right)$ and at frequency of $50 \mathrm{kHz}$ 


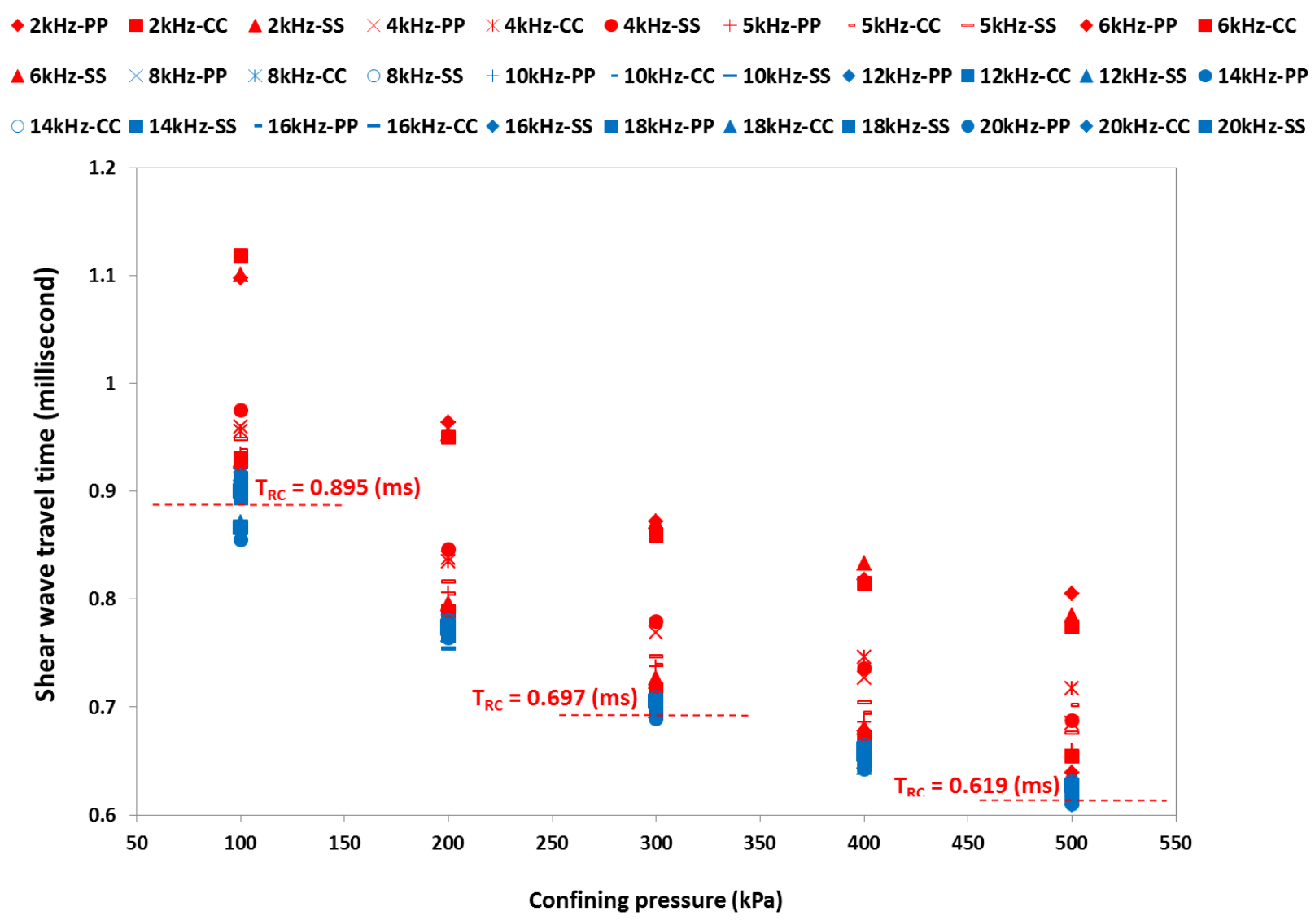

Fig. 7. Shear wave travel time (ms) measured by start-to-start (SS), peak-to-peak (PP), crosscorrelation $(\mathrm{CC})$, and resonant column test $(\mathrm{RC})$ for oven-dried Ottawa sand $\left(\mathrm{e}_{0}=0.715\right)$ 


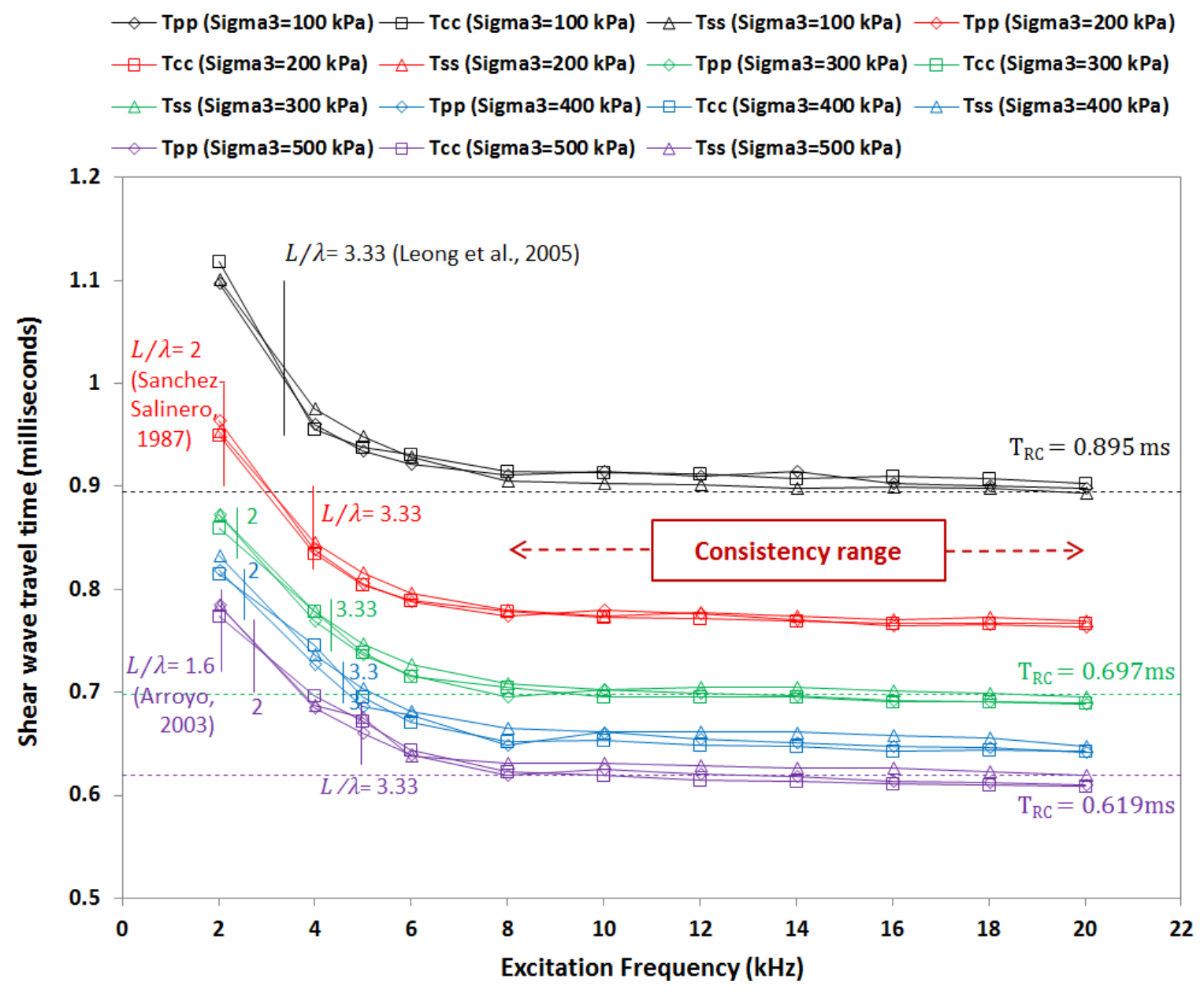

Fig. 8. Shear wave travel time $(\mathrm{ms})$ measured by start-to-start $\left(\mathrm{T}_{\mathrm{ss}}\right)$, peak-to-peak $\left(\mathrm{T}_{\mathrm{pp}}\right)$, crosscorrelation $\left(\mathrm{T}_{\mathrm{cc}}\right)$, and resonant column test $\left(\mathrm{T}_{\mathrm{RC}}\right)$ for oven-dried Ottawa sand $\left(\mathrm{e}_{0}=0.715\right)$ 

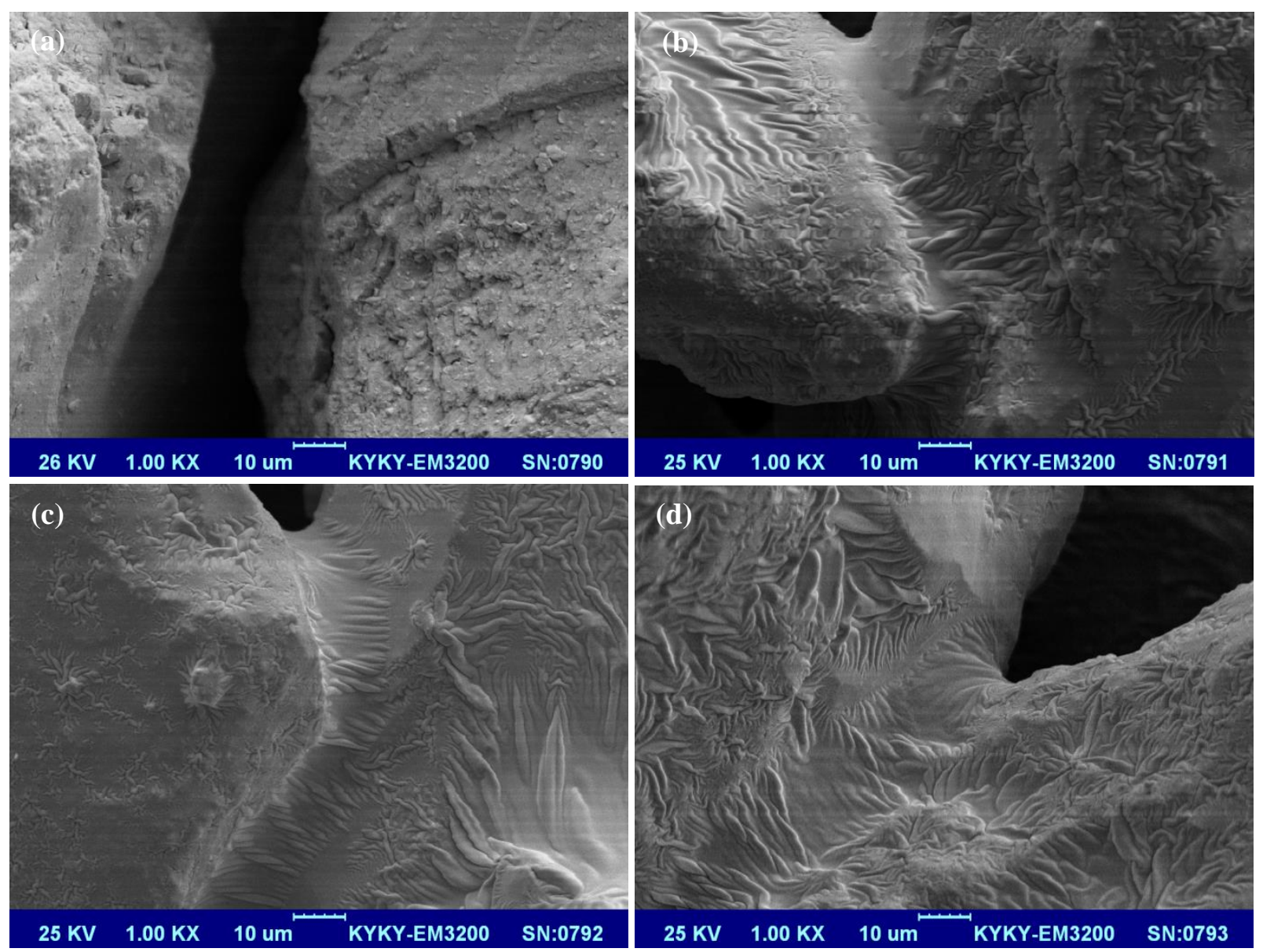

Fig. 9. SEM images of (a) clean oven-dried Ottawa sand, (b) 4 wt.\% light crude oil contaminated Ottawa sand, (c) 8 wt.\% light crude oil contaminated Ottawa sand, and (d) 12 wt.\% light crude oil contaminated Ottawa sand captured at 26000 Volt with scale bar of 10 um and magnification of $1.00 \mathrm{KX}$ 

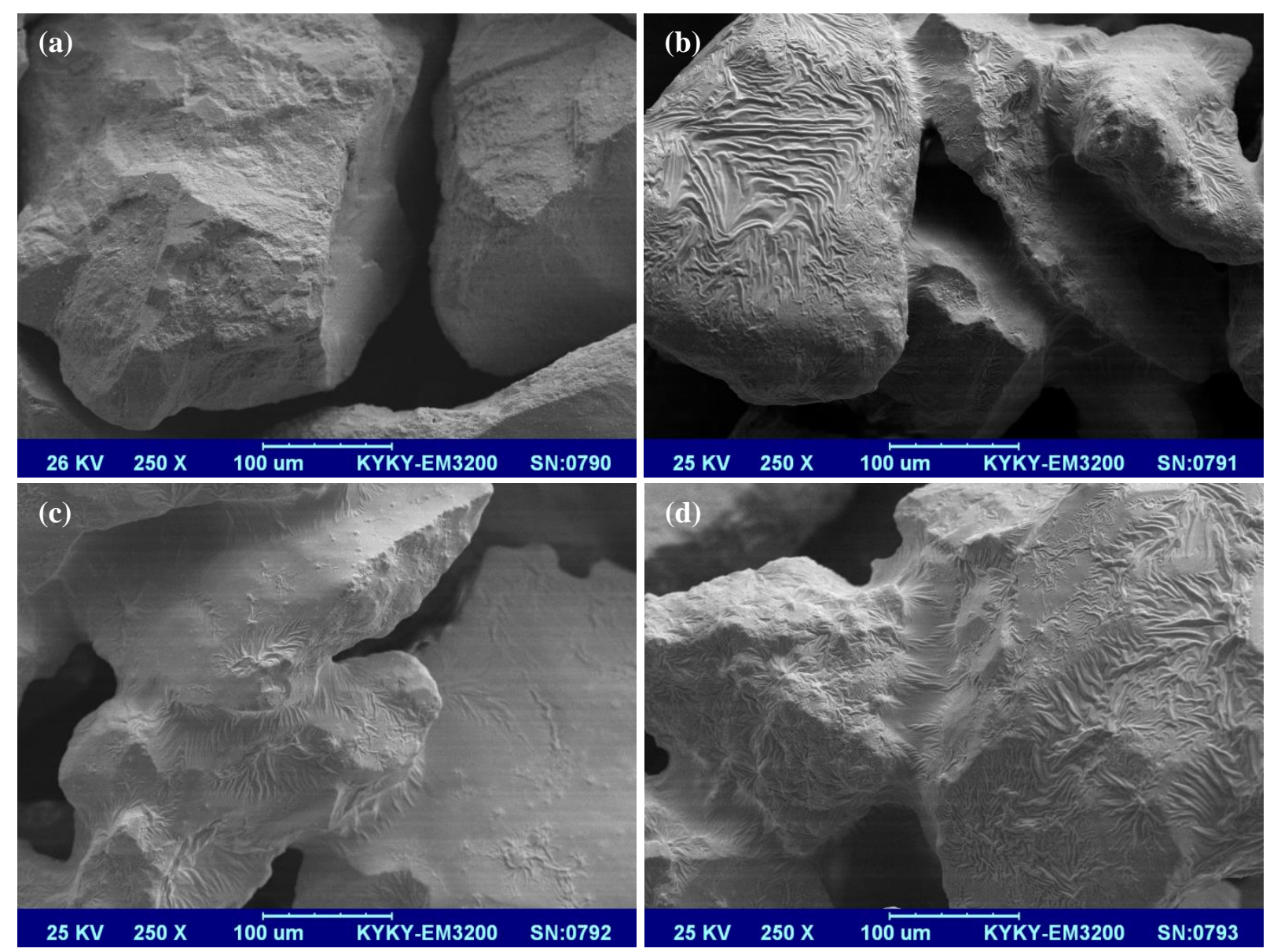

Fig. 10. SEM images of (a) clean oven-dried Ottawa sand, (b) 4 wt.\% light crude oil contaminated Ottawa sand, (c) 8 wt.\% light crude oil contaminated Ottawa sand, and (d) 12 wt.\% light crude oil contaminated Ottawa sand captured at 26000 Volt with scale bar of 100 um and magnification of $250 \mathrm{X}$ 


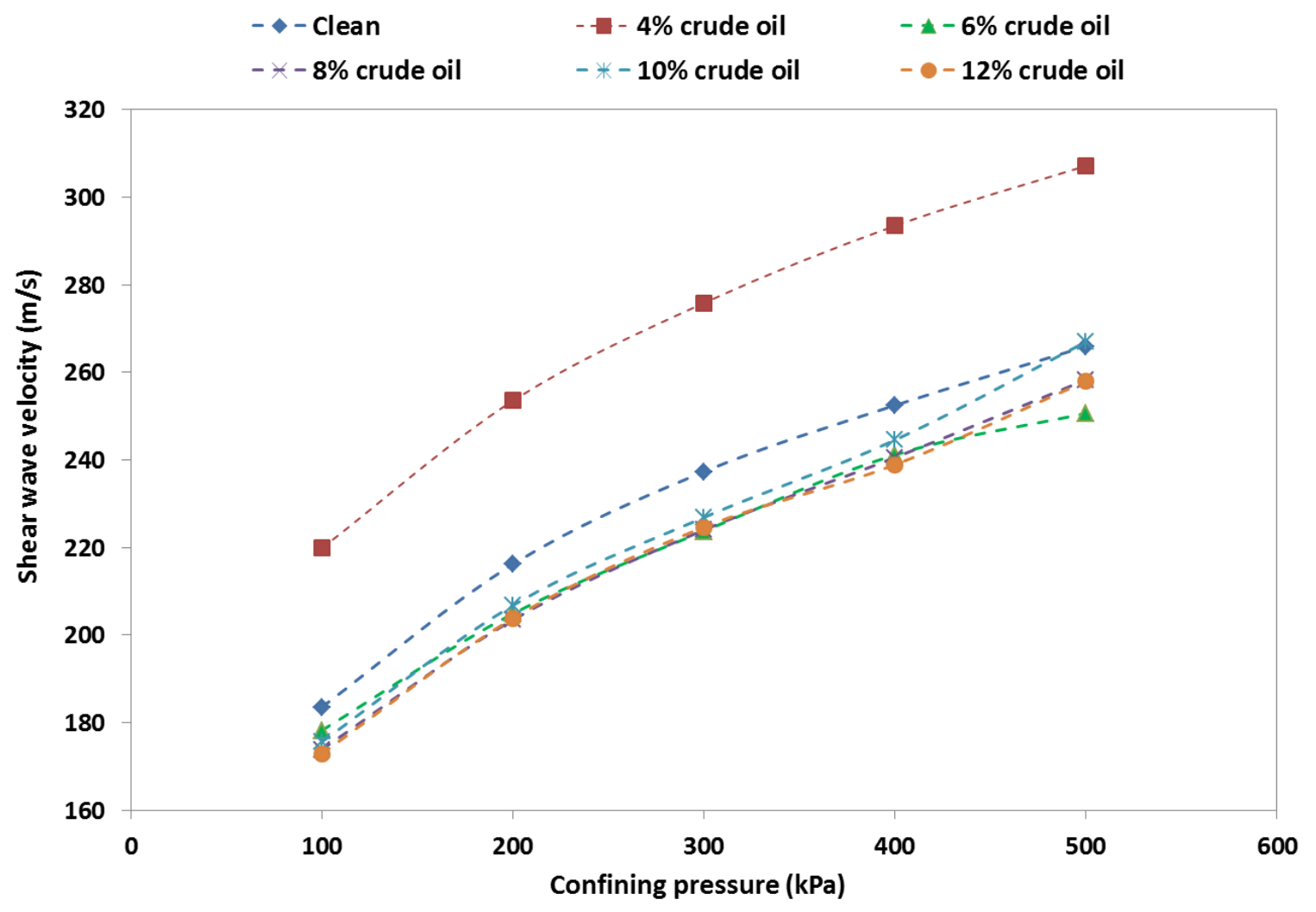

Fig. 11. Shear wave velocity $(\mathrm{m} / \mathrm{s})$ of clean and contaminated Ottawa sand by various light crude oil contents (4-12 wt.\%) with $\mathrm{e}_{0}=0.715$ at frequency of $10 \mathrm{kHz}$ for different confining pressures 
Fig. 12. Shear wave velocity $(\mathrm{m} / \mathrm{s})$ of clean and contaminated Ottawa sand by various light crude oil contents (4-12 wt.\%) with $\mathrm{e}_{0}=0.715$ at frequency of $10 \mathrm{kHz}$ for various amounts of contaminant 